\title{
Synthesis and functionalization of nitrosyl rhenacarboranes towards their use as drug delivery vehicles
}

Daniel G. Pruitt ${ }^{\text {, }}$, Sara M. Baumann ${ }^{\text {a }}$, Gregory J. Place ${ }^{\text {a }}$, Agozie N. Oyeamalu ${ }^{\text {, }}$, Ekkehard Sinn

${ }^{\mathrm{b}}$, Paul A. Jelliss ${ }^{\mathrm{a}, *}$

${ }^{a}$ Department of Chemistry, Saint Louis University, St Louis, Missouri, USA

${ }^{\mathrm{b}}$ Department of Chemistry, Western Michigan University, Kalamazoo, Michigan, USA

ABSTRACT

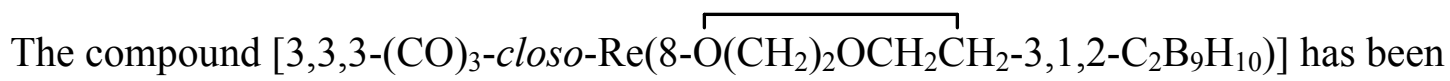

synthesized and used as precursor to several nitrosyl rhenacarborane complexes with boronbound $\mathrm{B}-\mathrm{O}\left(\mathrm{CH}_{2}\right)_{2} \mathrm{O}\left(\mathrm{CH}_{2}\right)_{2}-$ tethers to halo, amino and hydroxo functional groups. The last two in particular have afforded a pair of rhenacarborane derivatives, [3,3-(CO) $2-3-\mathrm{NO}-$ closo- $\mathrm{Re}(8-$ $\left.\left.\mathrm{O}\left(\mathrm{CH}_{2}\right)_{2} \mathrm{O}\left(\mathrm{CH}_{2}\right)_{2} \mathrm{NH}_{3}-3,1,2-\mathrm{C}_{2} \mathrm{~B}_{9} \mathrm{H}_{10}\right)\right] \mathrm{BF}_{4}$ and [3,3-(CO) $)_{2}-3-\mathrm{NO}-$ closo- $\mathrm{Re}(8-$ $\left.\mathrm{O}\left(\mathrm{CH}_{2}\right)_{2} \mathrm{O}\left(\mathrm{CH}_{2}\right)_{2} \mathrm{OH}-3,1,2-\mathrm{C}_{2} \mathrm{~B}_{9} \mathrm{H}_{10}\right)$ ], for potential use as drug-delivery vehicles. Bioconjugates tethering our delivery vehicles to amino acids or small peptides that are not readily transported across the blood-brain barrier, either by means of membrane-based transport mechanisms or through passive diffusion, could make potential pharmacological agents for central nervous system infiltration. The final nitrosyl complexes are made following nucleophilic ring opening of the $\beta$-boron-bound 1,4-dioxane moiety and our work has established that even with unprotected hydroxo and amino terminal groups, the metal can be selectively nitrosylated using $\left[\mathrm{NO}^{\circ}\left[\mathrm{BF}_{4}\right]\right.$ without destroying the integrity of the $\mathrm{B}-\mathrm{O}\left(\mathrm{CH}_{2}\right)_{2} \mathrm{O}\left(\mathrm{CH}_{2}\right)_{2} \mathrm{X}\left(\mathrm{X}=\mathrm{OH}, \mathrm{NH}_{3}\right)$ tether.

\footnotetext{
* Corresponding author. Tel. +001 (314) 9772834.

E-mail addresses: dpruitt1@slu.edu (D. G. Pruitt), jellissp@slu.edu (P. A. Jelliss).
} 
Keywords: rhenacarborane, drug delivery, blood-brain barrier, central nervous system

\section{Introduction}

The blood-brain barrier (BBB) is a regulatory gate of monolayers with tightly bound junctions that controls substance exchange between the blood and extracellular fluid in the central nervous system, communicating proper homeostatic regulation $[1,2]$. The capillary bed of endothelial cells in the vascular BBB is the primary obstacle to overcome in delivery of bioactive molecules into neurological tissues. There are numerous ways of crossover in the BBB including, but not limited to, transport proteins, vesicle passage and passive diffusion, the last of which enables many hydrophobic molecules with low molecular weights to move through the membrane $[3,4]$. Neutral carboranes and their metal based derivatives, in addition to their stability, can be very lipid-soluble because of their hydrophobic charge distribution, yet are not affected by the size constraint in crossing over the BBB and accumulating in neural tissue as they are not precursors in metabolic pathways for $p$-glycoprotein [5].

Metallacarborane complexes of heavier $d$-block transition metals often demonstrate robust thermodynamic and kinetic stabilities. This allows them to be considered for potential therapeutic or diagnostic applications as drug-delivery vehicles that resist metabolic degradation. Valliant and co-workers have investigated the chemistry of rhenacarborane complexes as part of an effort to develop convenient synthetic pathways to imaging reagents that incorporate the rhenium congener technetium, which is the most commonly used imaging radioisotope [6-8]. In particular, we are interested in developing rhenacarborane complexes derived from the useful 
precursor $\mathrm{Cs}\left[3,3,3-(\mathrm{CO})_{3}-\right.$ closo-3,1,2- $\left.\mathrm{ReC}_{2} \mathrm{~B}_{9} \mathrm{H}_{11}\right]$ (1) (Chart 1) as drug delivery vehicles for the central nervous system (CNS).

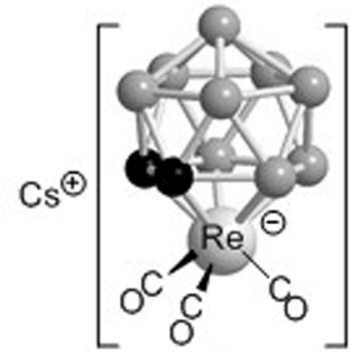

1

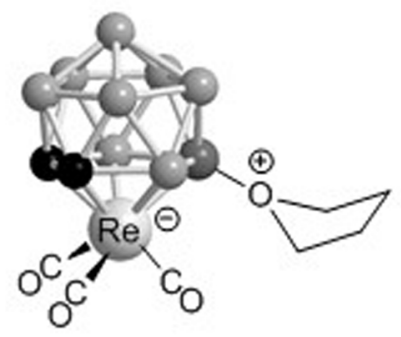

4a
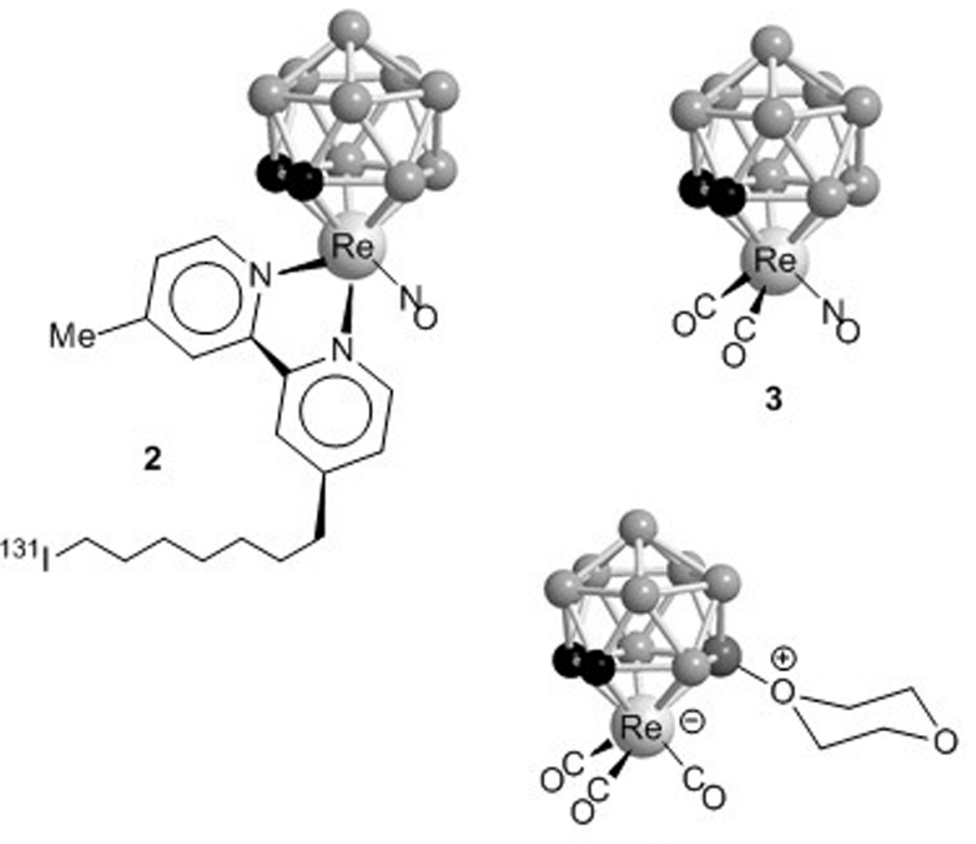

$4 b$

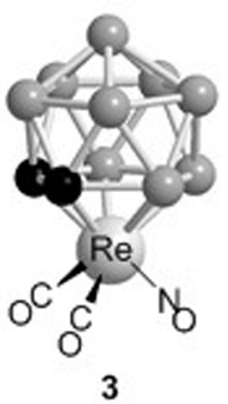

3

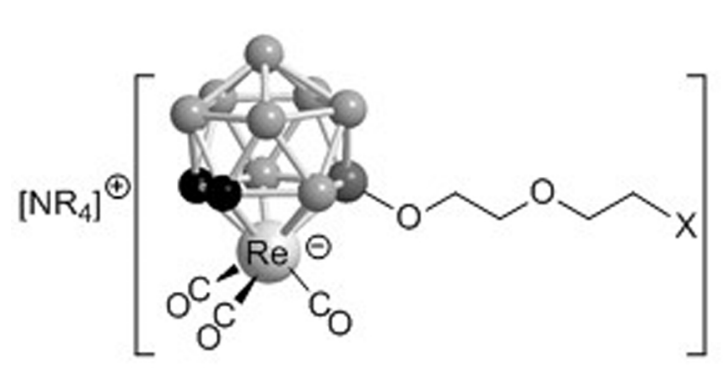

$\begin{array}{lll} & \mathrm{X} & \mathrm{R} \\ \mathbf{5 a} & \mathrm{Cl} & \mathrm{Et} \\ \mathbf{5 b} & \mathrm{Br} & \mathrm{Et} \\ \mathbf{5 c} & \mathrm{I} & \mathrm{Et} \\ \mathbf{5 d} & \mathrm{OBn} & \mathrm{Et} \\ \mathbf{5 e} & \mathrm{N}_{3} & \mathrm{Bu}^{n} \\ \mathbf{5 f} & \mathrm{OH} & \mathrm{Me}\end{array}$

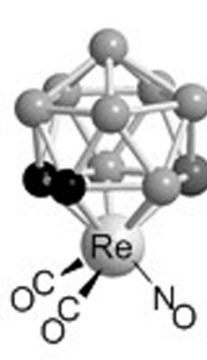


In preliminary studies with the ${ }^{131}$ I-labeled prototypical rhenacarborane complex [3-NO3,3- $\kappa^{2}-\left(2,2^{\prime}-\mathrm{N}_{2} \mathrm{C}_{10} \mathrm{H}_{6}(\mathrm{Me})\left\{\left(\mathrm{CH}_{2}\right)_{7}^{131} \mathrm{I}\right\}-4,4^{\prime}\right)-$ closo-3,1,2- $\left.\mathrm{ReC}_{2} \mathrm{~B}_{9} \mathrm{H}_{11}\right]$ (2), we have demonstrated the ability of a rhenacarborane to penetrate the BBB [9]. We determined rapid uptake and equilibrium phases with a steady state of ca. $0.1 \%$ of the injected dose being taken up per gram of CD-1 male mouse brain. The compound was shown to be stable in brain and blood as well as enzymatically resistant and thus a good candidate for targeting the CNS. Although complex 2 has an optimal partition coefficient $(1.74 \pm 0.13)$, suggesting it is sufficiently lipophilic to cross the BBB but not get trapped in the membrane, it is nevertheless challenging to synthesize because it comprises an asymmetric 2,2'-bipyridyl ligand. Thus we are investigating alternative but related rhenacarborane delivery vehicles to complex $\mathbf{2}$.

The nitrosyl complex [3-NO-3,3-(CO) $)_{2}$-closo-3,1,2- $\left.\mathrm{ReC}_{2} \mathrm{~B}_{9} \mathrm{H}_{11}\right]$ (3) was first reported by Stone et al a number of years ago [10]. As a neutral, non-polar rhenacarborane complex, it was shown to be lipophilic enough to be appreciably soluble in hexanes and is thus a potential candidate for a BBB delivery vehicle, providing it can be functionalized for conjugation with pharmacological payloads. We report herein new strategies to conveniently functionalize complex 1 at the $\beta$-boron vertex of the carborane ligand rather than directly at the metal center, maintaining the piano stool geometry and neutrality of complex $\mathbf{3}$ arising from the nitrosyl ligand.

\section{Results and discussion}

Complexes of the type [3,3,3-(CO) $)_{3}-8-\mathrm{L}-$-closo-3,1,2- $\left.\mathrm{ReC}_{2} \mathrm{~B}_{9} \mathrm{H}_{10}\right](\mathrm{L}=\mathrm{THF}, \mathbf{4 a} ; \mathrm{L}=1,4-$ dioxane, $\mathbf{4 b}$ ) are useful synthons for developing functionalization methodologies at a carborane boron vertex. Stone et al have shown that the $\beta$-B vertex in metallacarboranes in particular, is 
vulnerable to hydride extraction using suitable (often sterically hindered) electrophiles such as trityl, $\mathrm{Ph}_{3} \mathrm{C}^{+}[11]$. The related manganacarborane complex, [3,3,3-(CO) $)_{3}-8$-THF-closo-3,1,2$\left.\mathrm{MnC}_{2} \mathrm{~B}_{9} \mathrm{H}_{10}\right]$, however, was synthesized in low yield by direct reaction of $\mathrm{Cs}\left[3,3,3-(\mathrm{CO})_{3}\right.$-closo3,1,2- $\left.\mathrm{MnC}_{2} \mathrm{~B}_{9} \mathrm{H}_{11}\right]$ with methyl triflate $\left(\mathrm{CF}_{3} \mathrm{SO}_{3} \mathrm{Me}\right)$ as a source of $\mathrm{Me}^{+}[12]$. We have repeated essentially the same reaction using complex 1 with the same reagent $\left(\mathrm{CF}_{3} \mathrm{SO}_{3} \mathrm{Me}\right)$ and same conditions to afford complexes $\mathbf{4}$ in good yields ( $83 \%$ for $\mathbf{4 a}, 89 \%$ for $\mathbf{4 b}$ ) using THF and 1,4dioxane as solvents, respectively. Both complexes $\mathbf{4}$ are spectroscopically very similar with almost identical $v_{\max }(\mathrm{CO})$ absorptions $\left(1912\right.$ and $\left.2016 \mathrm{~cm}^{-1}\right)$ in their FTIR spectra. The appearance of these bands (with the lower energy band appearing more broad) is typical for a piano stool $\left(\eta^{5}-\mathrm{L}\right) \mathrm{M}(\mathrm{CO})_{3}$ architecture with a pseudo mirror plane of symmetry bisecting the metal, $\beta$ - $\mathrm{B}-\mathrm{O}$ bond in the coordinating carborane $\mathrm{CCB} B \mathrm{~B}$ face and one of the $\mathrm{CO}$ ligands. The ca. $15 \mathrm{~cm}^{-1}$ shift to higher energy relative to the starting anionic complex $\mathbf{1}$ is also expected for the formation of a zwitterionic species, with the formal positive charge residing on the donor oxygen of the solvent. The corresponding negative charge is understood to be delocalized around the $\mathrm{ReC}_{2} \mathrm{~B}_{9}$ pseudoaromatic cage framework. The substitution for hydrogen at the $\beta$ - $\mathrm{B}$ vertex is verified in both cases by observation in the ${ }^{11} \mathrm{~B}$ and ${ }^{11} \mathrm{~B}\left\{{ }^{1} \mathrm{H}\right\}$ NMR spectra of deshielded singlet resonances at $\delta 15.5(\mathbf{4 a})$ and $17.9(\mathbf{4 b})$, signals which remain uncoupled singlets in the ${ }^{11} \mathrm{~B}$ spectra. The chemical shift increase is also consistent with the binding of a neutral ethereal $\mathrm{O}$ donor. The ${ }^{1} \mathrm{H}$ and ${ }^{13} \mathrm{C}$ NMR spectra of complexes 4 are also in accordance with the pseudo $C_{\mathrm{s}}$ symmetry. Thus for $\mathbf{4 b}$, for example, single resonances are observed for the cage $\mathrm{C}-\mathrm{H}$ vertices at $\delta 2.82$ with two triplet signals $\left(J_{\mathrm{HH}}=4 \mathrm{~Hz}\right)$ for the proximal and distal pairs of $\mathrm{CH}_{2}$ 's of the 1,4dioxane at $\delta 4.27$ and 3.93, respectively. This is similarly reflected in the ${ }^{13} \mathrm{C}\left\{{ }^{1} \mathrm{H}\right\}$ NMR spectrum of $\mathbf{4 b}$ with carborane cage $\mathrm{C}-\mathrm{H}$ signals at $\delta 29.0$ and a pair of dioxane resonances at $\delta$ 
80.3 and 65.1. The deshielding of the chemical shifts for the proximal $\mathrm{CH}_{2}$ 's is indicative of the electrophilic nature of either of the carbon atoms in the asymmetrically bound 1,4-dioxane ring. It is precisely this reactivity that we expect to exploit in producing nitrosyl rhenacarborane complexes with tethering chains for pharmacological cargos. Because it will afford a slightly longer tethering chain, we have selected complex $\mathbf{4 b}$ as our principle reagent for these studies. Thus, as a first step, we have treated $\mathbf{4 b}$ with a series of simple nucleophiles to ring-open the 1,4dioxane (Scheme 1). Neutral nucleophiles are expected to retain the zwitterionic nature of the complex, albeit with a greater charge separation. Anionic nucleophiles will return the complex to an anionic state and lead to the isolation of a salt. Ultimately, our objective was to nitrosylate the rhenium using $[\mathrm{NO}]\left[\mathrm{BF}_{4}\right]$ to yield a $\operatorname{ReNO}(\mathrm{CO})_{2}$ vertex, as described for the synthesis of complex 3 .

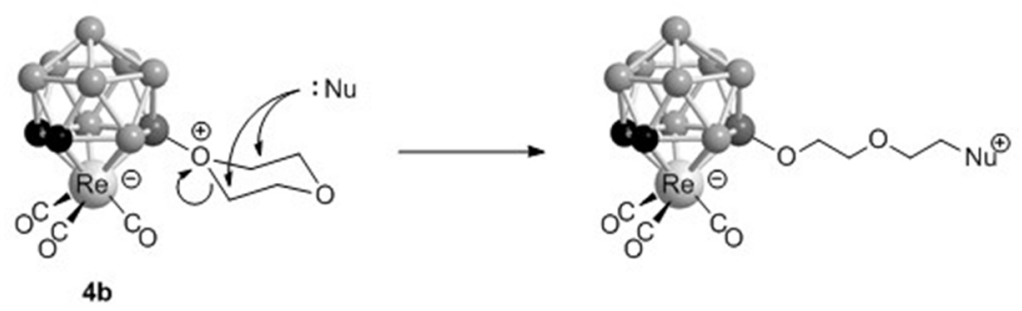

Sch. 1. Nucleophilic addition to the dioxo-moiety to generate pendant diether species.

With these outcomes in mind, we selected simple halides as the first simple salts to synthesize. Organic halides would not be expected to interfere with the ensuing nitrosylation step and furthermore, could be used as the basis for radiolabeling with ${ }^{131}$ I. Thus treatment of complex $4 \mathbf{b}$ with [ $\left.\mathrm{NEt}_{4}\right] \mathrm{X}(\mathrm{X}=\mathrm{Cl}, \mathrm{Br}, \mathrm{I})$ afforded salts 5a-c, respectively. Spectroscopically these three compounds are all very similar because once ring-opening has occurred, the halo functionality is sufficiently remote from the rhenacarborane cluster to exert little or no electronic impact. Thus the FTIR spectra are virtually identical with $v_{\max }(\mathrm{CO})$ resonances at 1902 and 2004 
$\mathrm{cm}^{-1}$, confirming reformation of the negatively charged $\mathrm{ReC}_{2} \mathrm{~B}_{9}$ cluster monoanion. Furthermore, all three ${ }^{11} \mathrm{~B}\left\{{ }^{1} \mathrm{H}\right\}$ NMR spectra comprise 5 peaks at ca. $\delta 17.7,-9.7,-17.0,-25.4$, and -30.0 with an integral ratio of $1: 3: 2: 2: 1$, respectively. The second peak likely results from fortuitous overlap of two (2:1) signals. Most importantly, the fully coupled ${ }^{11} \mathrm{~B}$ NMR spectrum reveals all but the low field signals at $\delta 17.7$ become doublets $\left(J_{\mathrm{BH}}=150 \mathrm{~Hz}\right)$, thus confirming retention of the $\beta$ $\mathrm{B}-\mathrm{O}$ bonds in all three complexes. The conversion of the 1,4-dioxane ring to a $\mathrm{O}\left(\mathrm{CH}_{2}\right)_{2} \mathrm{O}\left(\mathrm{CH}_{2}\right)_{2} \mathrm{X}$ open chain is verified in both the ${ }^{1} \mathrm{H}$ and ${ }^{13} \mathrm{C}\left\{{ }^{1} \mathrm{H}\right\}$ NMR spectra. As a representative example, the triplet resonances for the $\mathrm{O}\left(\mathrm{CH}_{2}\right)_{2} \mathrm{O}\left(\mathrm{CH}_{2}\right)_{2} \mathrm{X}$ methylene protons of complex $5 \mathbf{c}$ are observed at $\delta 3.75$ and $3.27\left(J_{\mathrm{HH}}=6.5 \mathrm{~Hz}\right)$ with the remaining pair of triplets coincident at $\delta 3.58$ due to the $\mathrm{O}\left(\mathrm{CH}_{2}\right)_{2} \mathrm{O}\left(\mathrm{CH}_{2}\right)_{2} \mathrm{X}$ methylenes (thus integrating to $4 \mathrm{H}$ and not sufficiently resolved to assign coupling constants). Assignments of methylene protons are more confidently made using 2D COSY NMR spectroscopy discussed below for complexes $6 \mathbf{6}$ and $\mathbf{8}$. The cage $\mathrm{C}-\mathrm{H}$ vertices are identified by a single broad resonance at $\delta 2.79$ and along with the observed peak integrals in the ${ }^{11} \mathrm{~B}$ NMR spectra indicate retention of the $C_{\mathrm{s}}$ symmetry in the cluster. The remaining quartet and triplet resonances ( $\delta 3.31$ and 1.39 , respectively) are attributed to the $\mathrm{CH}_{2}$ and Me groups of the $\mathrm{NEt}_{4}{ }^{+}$counterion and integrate accordingly. Thanks to the broader spectral width, all four $\mathrm{CH}_{2}$ carbon resonances are observed in the ${ }^{13} \mathrm{C}\left\{{ }^{1} \mathrm{H}\right\} \mathrm{NMR}$ spectrum at $\delta 71.7,71.2,69.3$, and 4.6 , although specific assignments cannot be made with certainty.

Although halo groups are potential precursors for other functional groups that can be directly exploited for conjugation to peptide cargos, we were particular interested in generating pendant amino or alcohol groups for amide and ester coupling to the carboxy terminus of small peptides, respectively. Because of potential interference with nitrosylating reagents, our 
preliminary targets were groups that could nevertheless be conveniently deprotected or converted as part of a work-up procedure following the nitrosylation step. For an alcohol, the simplest group envisaged was a benzoxy, $\mathrm{OBn}$, while for an amino precursor, we thought about azido, $\mathrm{N}_{3}$. Thus we treated complex $\mathbf{4 b}$ with Li[OBn], based on an adapted protocol from Vinas et al. [13], or $\left[\mathrm{NBu}^{n}\right]_{4}\left[\mathrm{~N}_{3}\right]$ to yield complex salts $\mathbf{5 d}$ and $\mathbf{5 e}$, respectively. Retention of pseudo $C_{\mathrm{S}}$ symmetry and the $\mathrm{B}-\mathrm{O}$ connectivity are once again confirmed by observation of broad deshielded signals ( $\delta 17.7(\mathbf{5 d})$ and $17.8(\mathbf{5 e})$ ), in the ${ }^{11} \mathrm{~B}\left\{{ }^{1} \mathrm{H}\right\}$ NMR spectra of both complexes (remaining as singlets in the fully coupled ${ }^{11} \mathrm{~B}$ NMR spectra). All other signals appear as expected for the carborane $\mathrm{C}-\mathrm{H}(\delta 2.78(\mathbf{5 d})$ and $2.75(\mathbf{5 e}))$, the methylene protons $\mathrm{B}-\mathrm{O}\left(\mathrm{CH}_{2}\right)_{2} \mathrm{O}\left(\mathrm{CH}_{2}\right)_{2} \mathrm{X}$ at $\delta$ $3.71,3.59$, and 3.38 resolving into triplets $\left(J_{\mathrm{HH}}=4.0,4.0,6.0 \mathrm{~Hz}\right.$, respectively) with an unresolved multiplet at $\delta 3.55$ that integrates 6:2 in relation to the other methylene protons (5e only), and benzoxy $\mathrm{OBn}$ groups $\left(\delta 4.52\left(\mathrm{OCH}_{2} \mathrm{Ph}\right)\right.$ and $7.37\left(\mathrm{OCH}_{2} \mathrm{Ph}\right)$ for $\mathbf{5 d}$ only $\left.)\right)$. However, unlike with complexes 5a-c,e, the four signals for the methylene protons are not discernible from one another, appearing as broad unresolved multiplets at $\delta 3.59(\mathbf{5 d})$. The other spectroscopic feature of note for complex 5e include the strong $v_{\max }(\mathrm{NN})$ stretch at $2105 \mathrm{~cm}^{-1}$ in the FTIR spectrum, consistent with the formation of an asymmetric organic azido group.

Having successfully created a boron-bound tethering diether chain, we next wanted to investigate whether complexes 5a-c could be nitrosylated at the metal center without degrading the tether or its connection to the cage. Treatment with 1 molar equivalent of $[\mathrm{NO}]\left[\mathrm{BF}_{4}\right]$ in THF at $-78^{\circ} \mathrm{C}$ caused an immediate color change from near colorless to intense yellow and afforded, following column chromatography on silica gel, the bright yellow complexes 6a-c. The replacement of one $\mathrm{CO}$ ligand with $\mathrm{NO}^{+}$leads to the complex becoming necessarily neutral with a $\mathrm{Re}^{\mathrm{I}}(\mathrm{CO})_{2} \mathrm{NO}$ vertex capping the nido- $\mathrm{C}_{2} \mathrm{~B}_{9}$ carborane cage cluster. This can be quickly inferred 
from the FTIR specta of the complexes, where a strong pair of $v_{\max }(\mathrm{CO})$ resonances (one sharp and one broad resulting from the $\operatorname{Re}(\mathrm{CO})_{3}$ piano stool legs) are replaced by two strong, sharp $v_{\max }(\mathrm{CO})$ resonances (e.g. 2033 and $2090 \mathrm{~cm}^{-1}$ for complex $\mathbf{6 c}$ ) and one medium intensity $v_{\max }(\mathrm{NO})$ resonance at $1780 \mathrm{~cm}^{-1}$. These may be favorably compared with those of the parent nitrosyl complex $3\left(v_{\max }(\mathrm{CO})\right.$ at 2034,2088 and $v_{\max }(\mathrm{NO})$ at $\left.1783 \mathrm{~cm}^{-1}\right)[10]$. The ${ }^{11} \mathrm{~B}\left\{{ }^{1} \mathrm{H}\right\}$ NMR spectrum for the three complexes show retention of the closo geometry bearing a pseudo $C_{\mathrm{s}}$ symmetry with a set of six signals between $\delta 22.4$ and -25.8 integrating to 1:1:2:2:2:1 as expected. The most deshielded signal at $\delta 22.4$ remains a singlet in the fully coupled ${ }^{11} \mathrm{~B}$ spectrum, which suggests that the $\beta$-B-O bond of the tether has not been cleaved by the highly electrophilic $\mathrm{NO}^{+}$reagent. Coupled with the FTIR spectroscopy, the metal vertex has clearly been targeted leading to substitution of one of the carbonyl ligands. Supporting this notion, is the observation in the ${ }^{1} \mathrm{H}$ NMR spectrum (of $\mathbf{6 c}$ for example) of correctly integrating signals attributed to the $\mathrm{B}-\mathrm{O}\left(\mathrm{CH}_{2}\right)_{2} \mathrm{O}\left(\mathrm{CH}_{2}\right)_{2} \mathrm{I}$ methylene protons at $\delta 3.76,3.57,3.52$, and 3.26 relative to the carborane $\mathrm{C}-\mathrm{H}$ vertices at $\delta 3.40$. The latter signal is readily identified from its broad appearance (and diagnostic chemical shift), while the other signals show discernible triplet couplings $\left(J_{\mathrm{HH}}=6.8\right.$ or $\left.7.2 \mathrm{~Hz}\right)$.

In order to verify that these nitrosylrhenacarborane complexes could be formed with intact pendant diether groups, an X-ray diffraction study was carried out on complex 6c. Single crystals were successfully grown from a $\mathrm{CH}_{2} \mathrm{Cl}_{2}$ solution of the complex layered with hexanes. The complex crystallizes as two independent molecules in a triclinic $P \overline{1}$ unit cell. There appear to be very few intramolecular structural differences between the two molecules and for the sake of brevity the features of just one of them are discussed and shown in Figure 1 (with the other 
shown in Supplementary Material Figure $\mathrm{S} 1$ ). The $\mathrm{ReC}_{2} \mathrm{~B}_{9}$ moiety comprises the usual closoicosahedral framework with an $\eta^{5}$-coordinated Re center. The distance from the metal to the unique $\beta$-B is somewhat longer (Re3-B8 2.368 $\AA$ ) than the other two (Re3-B4 2.338, Re3-B7 $2.306 \AA$ ), no doubt attributed to the presence of the O6 atom (B8-O6 1.428 $\AA$ ). The metal vertex comprises a $\operatorname{Re}(\mathrm{CO})_{2} \mathrm{NO}$ tripodal arrangement with near-linear nitrosyl (Re-N3-O3 $\left.171.76^{\circ}\right)$ and carbonyls (Re3-C4-O4 175.21, Re3-C5-O5 $\left.177.80^{\circ}\right)$. The presence of the iodine atom at the end of the $\mathrm{O}\left(\mathrm{CH}_{2}\right)_{2} \mathrm{O}\left(\mathrm{CH}_{2}\right)_{2}$ chain is also confirmed (C9-I1 2.157 $\AA$ ). Of interest to us is the disposition of the pendant $\mathrm{O}\left(\mathrm{CH}_{2}\right)_{2} \mathrm{O}\left(\mathrm{CH}_{2}\right)_{2} \mathrm{I}$ group with respect to the metallcarborane cluster framework. The chain clearly extends away from the metallacarborane (for both independent molecules) with no evidence of interaction with the $\mathrm{C}_{2} \mathrm{~B}_{9} \mathrm{H}_{11}$ ligand. This is more clearly seen in a crystallographic packing diagram viewed down the $b$ axis of the unit cell (Fig. 2). This perspective reveals a layered arrangement with two-dimensional aggregation of carborane cages along the $a c$ faces and the $\mathrm{ReNO}(\mathrm{CO})_{2}$ and $\mathrm{O}\left(\mathrm{CH}_{2}\right)_{2} \mathrm{O}\left(\mathrm{CH}_{2}\right)_{2} \mathrm{I}$ groups interdigitated in the space between. Clearly the more polar $\mathrm{O}\left(\mathrm{CH}_{2}\right)_{2} \mathrm{O}\left(\mathrm{CH}_{2}\right)_{2} \mathrm{I}$ chains show little interaction with the more hydrophobic carborane cage, a feature that might be expected to influence the membrane transport properties of the complex once a pharmacological cargo is attached. 


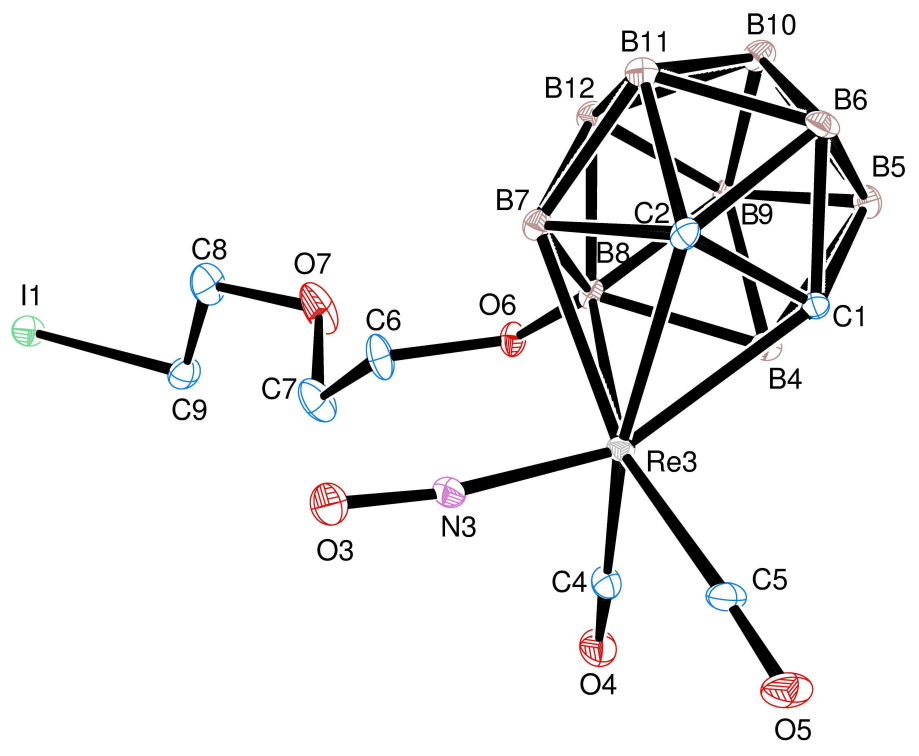

Fig. 1. Molecular structure of one of two independent molecules of complex $\mathbf{6 c}$ in crystal (hydrogen atoms removed for clarity). Selected bond lengths $(\AA)$ and angles $\left({ }^{\circ}\right)$ : Re3-B8 2.368(4), Re3-B4 2.338(5), Re3-B7 2.306(3), Re3-C2 2.279(5), Re3-C1 2.304(5); Re3-C4 1.952(5), Re3-C5 1.997(4), Re3-N3 1.795(4), B8-O6 1.428(7), C1 - C2 1.626(5), C4-O4 1.131(6), C5 - O5 1.137(4), C9-I1 2.157(5), N3-O3 1.175(6), Re3-N3-O3 171.8(3), Re3-C4O4 175.2(4), Re3-C5-O5 177.8(4), B8-O6-C6 116.6(4), C7-O7-C8 115.3(4).

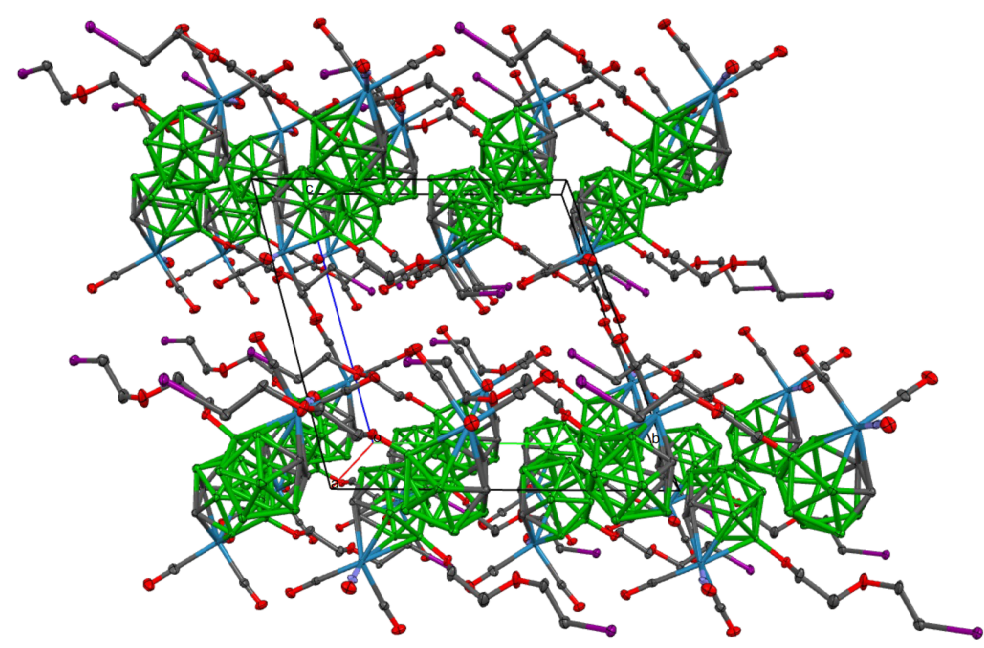

Fig. 2. Crystallographic packing diagram of $\mathbf{6 c}$ down the $b$ axis of the unit cell 
The next challenge was to nitrosylate complexes $\mathbf{5 d}$ and $\mathbf{5 e}$ using the same protocol. Irrespective of reaction conditions and reagents, complex $\mathbf{5 e}$ could not be successfully nitrosylated without incurring significant decomposition. Complex 5d, on the other hand, was quantitatively converted into $6 \mathbf{d}$ by treatment with $[\mathrm{NO}]\left[\mathrm{BF}_{4}\right]$ at $-78^{\circ} \mathrm{C}$. As with complexes $6 \mathbf{6}$ c, the cage remains intact according to the ${ }^{11} \mathrm{~B}\left\{{ }^{1} \mathrm{H}\right\}$ NMR spectra with resonances at $\delta 22.5,-2.3$, $-4.3,-13.3,-18.4$, and -26.2 integrating 1:1:2:2:2:1 with the first of these more deshielded signals remaining a singlet in the fully coupled ${ }^{11} \mathrm{~B}$ NMR spectrum. The benzoxy protecting group was thankfully not cleaved off under the acidic reaction conditions as confirmed by the observation in the ${ }^{1} \mathrm{H}$ NMR spectrum of a multiplet centered at $\delta 7.36$ integrating to 5 protons for the $\mathrm{Ph}$ group and a singlet resonance at $\delta 4.58$ attributed to the 2 benzoxy methylene protons. These signal integrations compare well with a series of multiplets (albeit poorly resolved) for the $\mathrm{O}\left(\mathrm{CH}_{2}\right)_{2} \mathrm{O}\left(\mathrm{CH}_{2}\right)_{2}$ methylene protons at $\delta 3.55$ that nevertheless integrate to 8 protons and the 2 protons of carborane $\mathrm{CH}$ vertices observed at $\delta 3.40$. The presence of all these groups are also confirmed by observation of appropriate signals in the ${ }^{13} \mathrm{C}\left\{{ }^{1} \mathrm{H}\right\}$ NMR spectrum.

The failed attempt to nitrosylate the azido species $\mathbf{5 e}$ notwithstanding, we proceeded to attempt to deprotect the benzoxy group of complex $\mathbf{6 d}$ using a variety of hydrogenation catalysts including $\mathrm{Pd} / \mathrm{C}$, solvents and other co-reagents. However with each and every protocol the benzoxy could not be cleaved off quantitatively from the pendant $\mathrm{O}\left(\mathrm{CH}_{2}\right)_{2} \mathrm{O}\left(\mathrm{CH}_{2}\right)_{2}$ group. Chromatographic and NMR analysis confirmed that most if not all of the benzoxy moiety remained bound to the diether unit, even after prolonged reaction times. Rather than continue with exhaustive fruitless deprotection attempts, we thought we ought to try a direct hydroxylation-nitrosylation sequence with complex $\mathbf{4 b}$. Thus complex $\mathbf{5 f}$ was first isolated in good yield and purified by treatment of $\mathbf{4} \mathbf{b}$ with one molar equivalent of $\left[\mathrm{NMe}_{4}\right][\mathrm{OH}] \cdot 5 \mathrm{H}_{2} \mathrm{O}$. As 
with complexes $5 \mathbf{a}-\mathbf{e}$, the $C_{\mathrm{s}}$ symmetrical nature of the cage is preserved as revealed by the ${ }^{11} \mathrm{~B}$ and ${ }^{11} \mathrm{~B}\left\{{ }^{1} \mathrm{H}\right\}$ NMR spectra. However, unlike with previous ring-opened diether chains, the $\mathrm{O}\left(\mathrm{CH}_{2}\right)_{2} \mathrm{O}\left(\mathrm{CH}_{2}\right)_{2} \mathrm{OH}$ chain produced a series of poorly resolved methylene proton resonances at centered at $\delta 3.57$. Nevertheless, when compared with the resonance for the symmetryequivalent cage $\mathrm{C}-\mathrm{H}$ resonances at $\delta 2.90$, the relative integration is exactly $8: 2$, respectively. Additionally, because the ${ }^{1} \mathrm{H}$ NMR spectrum was run in aprotic $\mathrm{CD}_{3} \mathrm{CN}$ solvent, the hydroxyl proton could be clearly observed at $\delta 3.67$, integrating to one proton. The ${ }^{13} \mathrm{C}\left\{{ }^{1} \mathrm{H}\right\} \mathrm{NMR}$ spectrum clearly delineates the diether methylene carbon nuclei, with four singlet resonances observed at $\delta 71.6,70.4,69.2$, and 61.5 for the $\mathrm{C}^{\mathrm{B}}, \mathrm{C}^{\mathrm{C}}, \mathrm{C}^{\mathrm{A}}$, and $\mathrm{C}^{\mathrm{D}}$ methylene carbons, respectively. This is in addition to the Re-carbonyl and cage $\mathrm{C}$ vertex signals at $\delta 198.9$ and 26.8, respectively.

Nitrosylation of complex $\mathbf{5 f}$ to afford neutral complex $\mathbf{6} \mathbf{f}$ using $[\mathrm{NO}]\left[\mathrm{BF}_{4}\right]$ proceeded smoothly and in reasonable yield, suggesting that the gamble to nitrosylate in the presence of an unprotected hydroxyl group paid off. The FTIR spectrum revealed $v_{\max }(\mathrm{CO})$ resonances at 2033 and $2091 \mathrm{~cm}^{-1}$ and a broad $v_{\max }(\mathrm{NO})$ resonance at $1786 \mathrm{~cm}^{-1}$, very similar to those of complexes 6a-d. This confirms the clean conversion from a $\operatorname{Re}(\mathrm{CO})_{3}$ vertex to a $\operatorname{ReNO}(\mathrm{CO})_{2}$ one, thus retaining the intact closo $-\mathrm{ReC}_{2} \mathrm{~B}_{9}$ architecture. This is further verified by the now routine observation of six signals between $\delta 22.4$ and -25.3 (integral values 1:1:2:2:2:1) with highest of these retaining its singlet character in the fully coupled ${ }^{11} \mathrm{~B}$ NMR spectrum and thus reflecting the presence of the $\mathrm{B}-\mathrm{O}$ bond to the diethyl-alcohol chain. More importantly, the $\mathrm{BO}\left(\mathrm{CH}_{2}\right)_{2} \mathrm{O}\left(\mathrm{CH}_{2}\right)_{2} \mathrm{OH}$ chain was not compromised by the nitrosylation reaction. Thus the cage $\mathrm{CH}$ protons resonate at $\delta 3.42$ with an integration of 2 protons. Three diether methylene proton 
resonances overlap at $\delta 3.53$ while the fourth is discernible at $\delta 3.74$ (integrating 6:2) with triplet coupling $\left(J_{\mathrm{HH}}=8 \mathrm{~Hz}\right)$, presumably to the adjacent methylene group in the chain.

The synthesis of complex $\mathbf{6 f}$ represents the formation of the first viable drug delivery agent in our cache. The pendant hydroxyl functionality is primed for ester formation with the carboxy terminus of peptide pharmacophores. Another option is to produce a terminal amino group, which can be utilized for amide coupling to the same pharmacophores.

We again began with our synthon $\mathbf{4 b}$ and wanted to fall back on a more simplistic synthetic scheme after the shortcomings seen with the azido complex 5e. Much like the direct pathway discovered for $\mathbf{6 f}$, we decided to attempt direct amine functionalization on the end of the diether pendant chain before performing the nitrosylation step. Treatment of $\mathbf{4 b}$ with $\left[\mathrm{NH}_{4}\right][\mathrm{OH}]$ yielded the zwitterionic species 7 with a terminal primary ammonium group at the end of the diether chain. Spectroscopically, we can identify the reformation of a monoanionic metallacarborane unit with $v_{\max }(\mathrm{CO})$ resonances at 1908 and $2007 \mathrm{~cm}^{-1}$ in the FTIR spectrum. Moreover, familiar ${ }^{11} \mathrm{~B}\left\{{ }^{1} \mathrm{H}\right\} \mathrm{NMR}$ resonances are seen in the range $\delta 16.5$ to -29.1 with peak integral ratios of $1: 3: 2: 2: 1$, showing fortuitous overlap of two signals for the $3 \mathrm{~B}$ signal. The formation of the linear diether ammonium from the cyclic 1,4-dioxane ether can be verified from ${ }^{1} \mathrm{H}$ and ${ }^{13} \mathrm{C}\left\{{ }^{1} \mathrm{H}\right\}$ NMR spectra as measured in $\mathrm{CD}_{3} \mathrm{CN}$. Singlet resonances can be observed at $\delta$ 6.78 and 2.96, integrating 3:2 arising from the $-\mathrm{NH}_{3}{ }^{+}$group and the two cage $\mathrm{C}-\mathrm{H}$ protons, respectively. A series of signals for the methylene protons are also observed with triplets at $\delta$ 3.72, 3.59, and $3.09\left(J_{\mathrm{HH}}=5.1,4.4\right.$, and 5.3, respectively) and an unresolved broad signal appearing at $\delta 3.46$, probably due to proximity to the $\beta$-B $(I=3 / 2)$ of the carborane cluster. The 
methylene carbon signals can be seen in the ${ }^{13} \mathrm{C}\left\{{ }^{1} \mathrm{H}\right\}$ NMR spectrum at $\delta 70.1,70.0,65.5$, and 51.5 .

Although we had some concern about the propensity of the ammonium group to withstand the nitrosylation process without being degraded, we suspected that owing to its production as cationic ammonium species, the localized positive charge on the terminus of the pendant chain would repel the $\mathrm{NO}^{+}$cation and direct nitrosylation solely at the metal center to form complex $\mathbf{8}$. Through examination of the FTIR spectrum, complete substitution of a CO ligand with $\mathrm{NO}^{+}$is demonstrated with two $v_{\max }(\mathrm{CO})$ resonances 2031 and $2089 \mathrm{~cm}^{-1}$ and one medium intensity $v_{\max }(\mathrm{NO})$ resonance at $1780 \mathrm{~cm}^{-1}$. The formerly catonic complex was isolated as a tetrafluoroborate salt as shown in the ${ }^{11} \mathrm{~B}\left\{{ }^{1} \mathrm{H}\right\}$ NMR spectrum with a very strong, sharp peak at $\delta 1.1$, characteristic of the $\mathrm{BF}_{4}^{-}$counter ion. The pseudo $C_{\mathrm{s}}$ symmetry of the structure is preserved with six signals observed for the cage boron vertices at $\delta 20.9,-3.6,-5.3,-13.5,-$ 19.2, and -25.4 integrating to $1: 1: 2: 2: 2: 1$ with the furthest downfield signal remaining as a singlet in the ${ }^{11} \mathrm{~B}$ spectrum, showing retention of the cage-diether chain $\mathrm{B}-\mathrm{O}$ bond. The ${ }^{1} \mathrm{H}$ NMR spectrum reveals methylene proton signals at $\delta 3.68,3.56,3.45$, and 3.14 that integrate $2: 2: 2: 2: 2$ with respect to the carborane cage $\mathrm{C}-\mathrm{H}$ protons, which produces a characteristic broad singlet resonating at $\delta 3.76$. The methylene protons show unresolved splitting due to coupling between protons of directly adjacent methylene groups, but the only fully resolved triplet is at $\delta 3.68\left(J_{\mathrm{HH}}\right.$ = 5.12). The methylene carbons appear in the ${ }^{13} \mathrm{C}\left\{{ }^{1} \mathrm{H}\right\}$ NMR spectrum at $\delta 71.2,70.3,66.8$, and 41.1.

Two dimensional COSY ${ }^{1} \mathrm{H}\left\{{ }^{11} \mathrm{~B}\right\}$ NMR spectroscopy (Fig. 3) was used to specifically assign the chemical shift values from the ${ }^{1} \mathrm{H}$ NMR spectrum to the methylene protons on the 
diether chain, keeping in mind the signal locations of the $\mathrm{CH}_{2}$ protons as the $\mathrm{B}-\mathrm{H}$ hydrogens also appear due to decoupling from the boron nuclei. This 2D spectral analysis clearly reveals the cage B-H resonances at $\delta 4.46,2.64,2.28,2.21$, and 2.14 integrating to a 1:2:2:1:2 ratio, as well as the cage $\mathrm{C}-\mathrm{H}$ protons previously identified at $\delta 3.76$. However, it is the ammonium and methylene resonances that produce observable off-diagonal correlations. Because aprotic $\mathrm{CD}_{3} \mathrm{CN}$ is used as the NMR solvent, the proton signal for the $-\mathrm{NH}_{3}{ }^{+}$triplet signal is clearly seen at $\delta$ 6.31. Most striking, this resonance correlates directly with the $\mathrm{CH}_{2}$ resonance at $\delta 3.13$, permitting this to be assigned to the terminal methylene group, A. This in turn correlates with the resonances at $\delta 3.68$ for methylene group B. This leaves correlations between resonances at $\delta$ 3.56 and 3.45, assigned to the inner methylene groups $\mathrm{C}$ and $\mathrm{D}$, with the latter attributed specifically to the proximal methylene to the cage $\beta$-B vertex (quadrupolar nuclear spin, $I=3 / 2$ ). This is most clearly seen in the ${ }^{11} \mathrm{~B}$-decoupled ${ }^{1} \mathrm{H}$ 1D NMR spectrum (Figure S2 in Supplementary Material). 

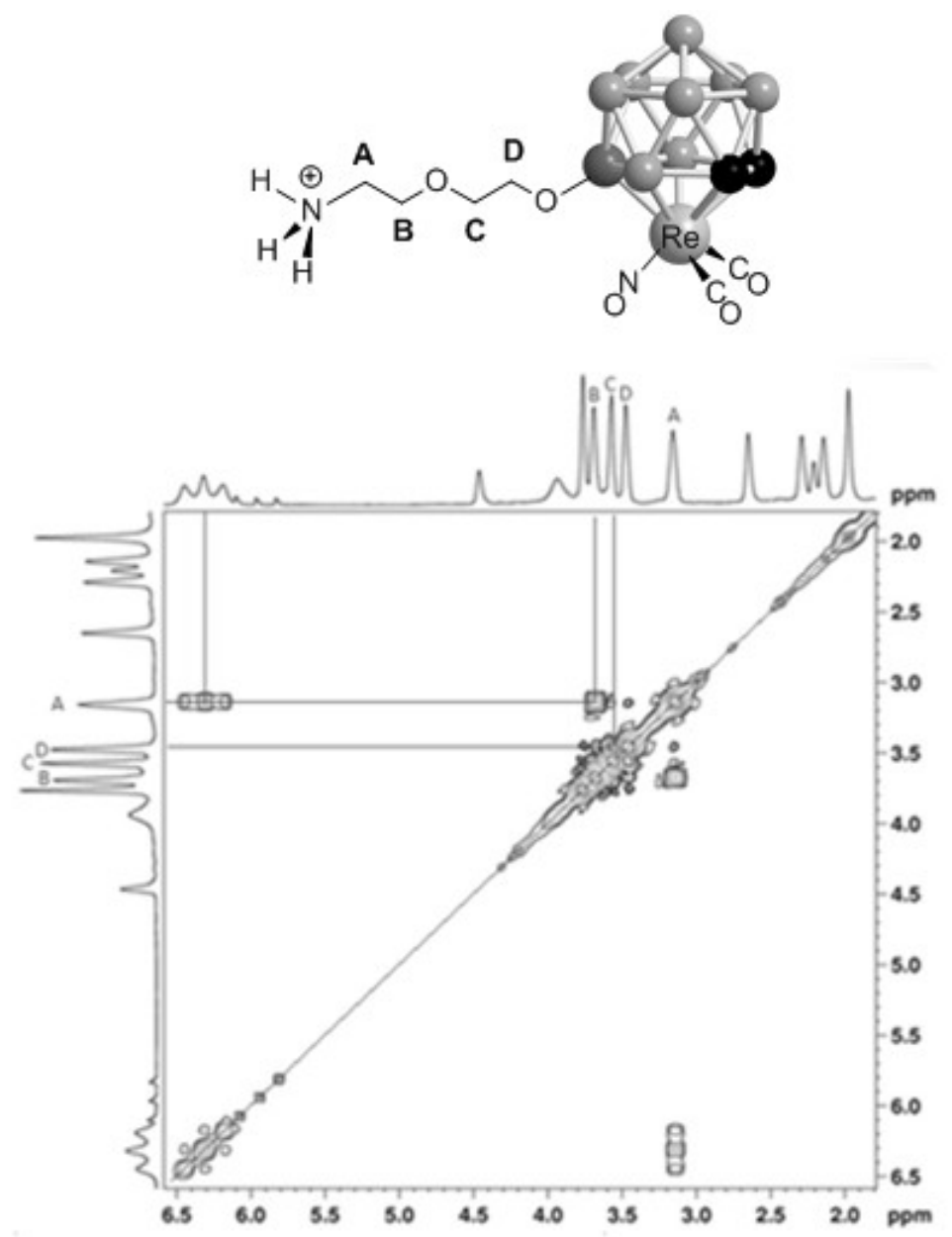

Fig. 3. Two dimensional $\operatorname{COSY}{ }^{1} \mathrm{H}\left\{{ }^{11} \mathrm{~B}\right\}$ NMR spectrum of compound $\mathbf{8}$.

Interestingly, a significant difference was observed between the appearance of the $-\mathrm{NH}_{3}{ }^{+}$ resonances for complexes $\mathbf{7}$ and $\mathbf{8}$. For the former (7), a broad singlet is observed $(\delta 6.78)$, while for the latter $(\mathbf{8})$, clear triplet splitting is observed owing to ${ }^{14} \mathrm{~N}-{ }^{1} \mathrm{H}$ coupling $\left(J_{\mathrm{NH}}=52 \mathrm{~Hz}\right)$. The broadness of both signals (compared with $\mathrm{CH}_{2}$ resonances, for example) can be attributed to the quadrupolar ${ }^{14} \mathrm{~N}(I=1)$ nucleus and not any significant proton exchange (the measurements are made in aprotic $\mathrm{CD}_{3} \mathrm{CN}$ ). Typically such coupling is washed out by scalar relaxation, although it may be observed in high symmetry systems (such as $\mathrm{NH}_{4}{ }^{+}$) [14]. This suggests that in complex 8, free rotation about the $\mathrm{H}_{2} \mathrm{C}-\mathrm{NH}_{3}{ }^{+}$bond is occurring in solution, thus preserving local $C_{3 \mathrm{v}}$ 
symmetry at the nitrogen. In complex 7 , however, the coupling may not be observed due to loss of such symmetry, perhaps due to formation of intermolecular, or more likely intramolecular, $\mathrm{CH}_{2}-\mathrm{NH}_{3}{ }^{+} \ldots{ }^{\delta} \mathrm{H}-\mathrm{B}$ bonding with the anionic rhenacarborane vertices (Fig. 4). Nitrosylation eliminates the excess negative charge and probably the protic-hydridic interaction along with it.

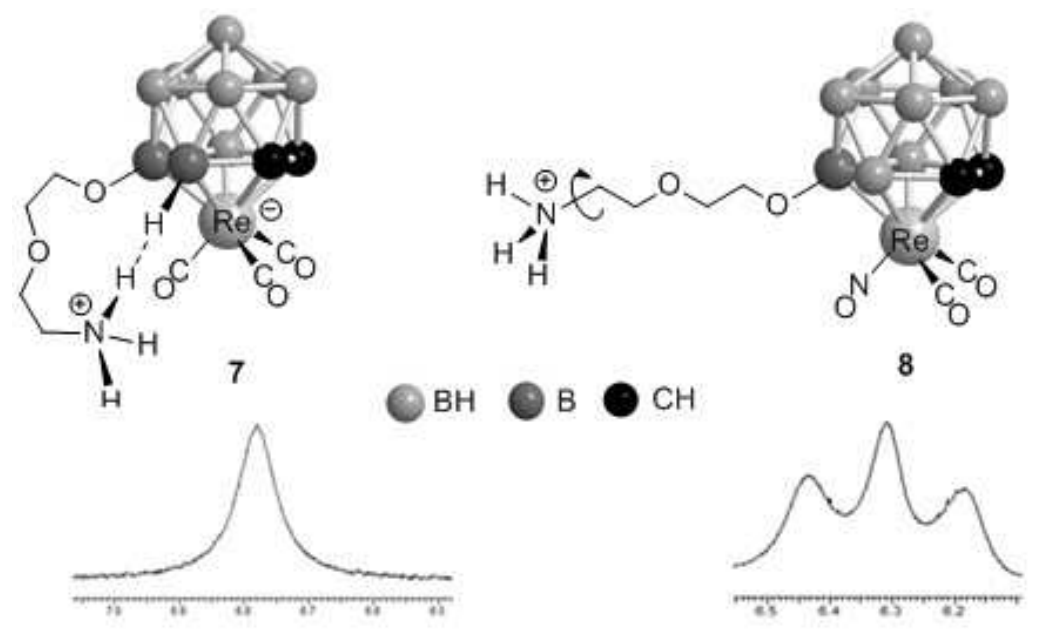

Fig. 4. Effect of intramolecular proton-hydride interaction on ${ }^{14} \mathrm{~N}-{ }^{1} \mathrm{H}$ coupling in the ${ }^{1} \mathrm{H}$ NMR spectrum of complexes $\mathbf{7}$ and $\mathbf{8}$.

While existing as a tetrafluoroborate salt, compound $\mathbf{8}$ still serves as a second potential drug delivery vehicle to add to our repertoire. Whereas target structures to be subjected to physiological conditions are required to be neutral, the primary ammonium cation can either be removed via deprotonation prior to any subsequent reaction or as part of the coupling strategy for connection to the carboxy terminus of a target amino acid or peptide. Work to develop and optimize coupling protocols for complexes $\mathbf{6} \mathbf{f}$ and $\mathbf{8}$ with single amino acids (e.g. tyrosine) and peptides (e.g. methionine-enkephalin) is currently under way.

In the mean time we also wanted to produce a structure that could be easily radiolabeled to probe the physiological tissue distribution of these nitrosyl rhenacarborane diether moieties to 
compare with the original prototype complex $\mathbf{2}$, showcasing potential differences between derivation at a cage vertex as opposed to an ancillary ligand such as 4,4'-bipyridyl. We sought to use a synthetic protocol that would allow the iodo group of $\mathbf{6} \mathbf{c}$ to be conveniently converted into its radioactive counterpart, ${ }^{131}$ I, by replacing iodine with a stable, yet facile leaving group [15]. A trifluoromethane sulfonate $\mathrm{OTf}^{-}$group was selected as the temporary placeholder for the iodo moiety as $\mathbf{6 c}$ was treated with $\mathrm{Ag}[\mathrm{OTf}]$ to quantitatively afford compound $\mathbf{6 e}$. Metallacarborane cage symmetry with the pendant $-\mathrm{O}\left(\mathrm{CH}_{2}\right)_{2} \mathrm{O}\left(\mathrm{CH}_{2}\right)_{2}$ moiety is maintained with ${ }^{11} \mathrm{~B}\left\{{ }^{1} \mathrm{H}\right\}$ NMR resonances observed at $\delta 22.4,-2.2,-4.0,-13.1,-18.0$, and -25.4 integrating with a ratio of 1:1:2:2:2:1 and the most downfield signal remaining a singlet in ${ }^{11} \mathrm{~B}$ NMR spectrum, thus confirming the B-O bond stability. Successful conversion from iodo to triflato was observed in the ${ }^{1} \mathrm{H}$ NMR spectrum, with resolved proton triplets at $\delta 4.01,3.19$, and $3.14\left(J_{\mathrm{HH}}=4.4,5.0\right.$, and 4.5 , respectively) with a broad unresolved multiplet observed at $\delta 3.39$, integrating $6: 2$ with respect to the other methylene protons. A $2 \mathrm{H}$ resonance was observed for the carborane $\mathrm{C}-\mathrm{H}$ protons at $\delta 2.28$. Through the examination of the $2 \mathrm{D} \operatorname{COSY}{ }^{1} \mathrm{H}$ NMR spectrum (Figure $\mathrm{S} 3$ in Supplementary Material), it can be deduced that the most deshielded signal at $\delta 4.01$ is attributed to the methylene protons on the carbon adjacent to the trifluoromethane sulfonate group. Additionally we can see that the splitting observed in these protons is due to the protons yielding the triplet resonance observed at $\delta 3.14$. The broadening seen in the ${ }^{1} \mathrm{H}$ NMR for the pair of protons at $\delta 3.39$ was credited to their proximity to the $3 / 2$ spin nuclei at the $\beta$-B vertex, which leaves the signal at $\delta 3.19$ remaining to be due to the pair of proximal protons, which is confirmed through the COSY correlation. Pharmacological studies based on the conversion of complex $6 \mathbf{e}$ to a ${ }^{131}$ I-labelled species will be reported in due course.

\section{Conclusions}


The modification of the $\beta-\mathrm{B}$ vertex of $\mathrm{Cs}\left[3,3,3-(\mathrm{CO})_{3}-\right.$ closo-3,1,2- $\left.\mathrm{ReC}_{2} \mathrm{~B}_{9} \mathrm{H}_{11}\right]$ (1) to attach a cyclic dioxo-structure to yield compound $\mathbf{4 b}$ proved to be an effective first step in the creation of a cache of compounds which lead to the development of two potential drug delivery vehicles. Integration of terminal ammonium and hydroxyl functionalities onto the diether chain provide the ability for the complexes to undergo coupling to amino acids and peptide sequences. The future synthesis of these vehicle-peptide bioconjugates will hopefully shed light onto latent CNS therapeutics pending the enzymatic susceptibility of amide and ester functionalities inside neural tissues.

\section{Experimental methods}

\subsection{Materials and reagents}

Methylene chloride and hexanes, tetrahydrofuran, and 1,4-dioxanes were freshly distilled over calcium hydride, potassium, and 4A molecular sieves respectively under a dry argon atmosphere to remove any water and oxygen. Methanol was used as shipped for column chromatography. Anhydrous sodium sulfate was used as shipped as a drying agent. Tetrabutylammonium azide, tetraethylammonium chloride hydrate, tetraethylammonium bromide, tetraethylammonium iodide, tetramethylammonium hydroxide pentahydroxide, benzyl alcohol, $n$-butyl lithium, and nitrosonium tetrafluoroborate were all supplied by Sigma Aldrich.

\subsection{Instrumentation}

NMR measurements were made using a Bruker Avance $400 \mathrm{MHz}$ NMR spectrometer. Infrared measurements were performed in solution cells with $\mathrm{CaF}_{2}$ plates using a Shimadzu FTIR $8400 \mathrm{~S}$ spectrometer. Microanalysis performed by Atlantic Microlabs. FAB Mass 
spectrometry performed on a JOEL MStation [JMS-700] Mass Spectrometer at University of Missouri - St. Louis.

\subsection{General synthetic methods}

All reactions were carried out under a dry, inert argon atmosphere using Schlenk line techniques stirring rapidly using a magnetic stir plate.

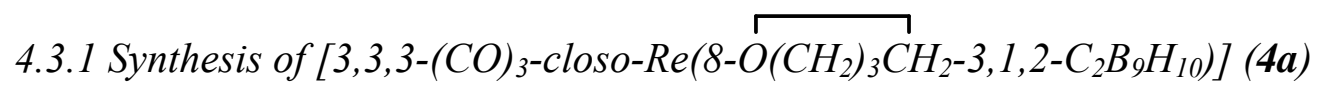

A solution containing $75 \mathrm{mg}(0.14 \mathrm{mmol})$ of the cesium salt of the parent complex 1 in 50 $\mathrm{mL}$ of dry tetrahydrofuran was treated with $27 \mu \mathrm{L}(0.14 \mathrm{mmol})$ of $\mathrm{CF}_{3} \mathrm{SO}_{3} \mathrm{Me}$ and set to reflux. The progress of the reaction was determined complete using infrared spectroscopy after $2 \mathrm{~h}$ of stirring. The solvent was removed in vacuo to yield a crude product. The product was reconstituted in methylene chloride and run through an alumina column. The solvent was removed from the eluted product via rotovap producing a crystalline product. The reaction yielded $55 \mathrm{mg}(83 \%)$ of powdered, pale tan product.

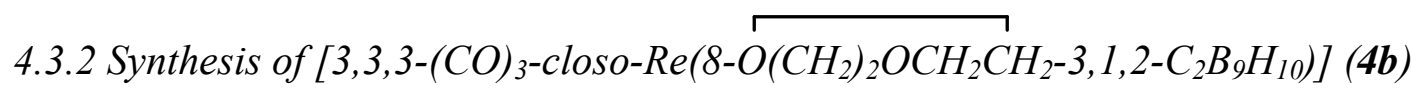

A solution containing $2.00 \mathrm{~g}(3.73 \mathrm{mmol})$ of the cesium salt of the parent complex $\mathbf{1}$ in $100 \mathrm{~mL}$ of dry 1,4-dioxane was treated with $410 \mu \mathrm{L}(3.73 \mathrm{mmol})$ of $\mathrm{CF}_{3} \mathrm{SO}_{3} \mathrm{Me}$ and set to reflux. The progress of the reaction was determined complete using infrared spectroscopy after $2 \mathrm{~h}$ of stirring. The solvent was removed in vacuo to yield a crude product. The product was reconstituted in methylene chloride and run through an alumina column. The solvent was removed from the eluted product via rotovap producing a crystalline product. The reaction yielded $1.62 \mathrm{~g}(89 \%)$ of powdered, pale tan product. 


\subsubsection{Synthesis of $\left[\mathrm{NEt}_{4}\right]\left[3,3,3-(\mathrm{CO})_{3}-\mathrm{closo}-\mathrm{Re}\left(8-\mathrm{O}\left(\mathrm{CH}_{2}\right)_{2} \mathrm{O}\left(\mathrm{CH}_{2}\right)_{2} \mathrm{Cl}-3,1,2-\mathrm{C}_{2} \mathrm{~B}_{9} \mathrm{H}_{10}\right)\right](\mathbf{5 a})$}

A solution containing $50 \mathrm{mg}(0.10 \mathrm{mmol}) \mathbf{4 b}$ in $25 \mathrm{~mL} \mathrm{CH} \mathrm{Cl}_{2}$ was treated with $16.9 \mathrm{mg}$ $(0.10 \mathrm{mmol})\left[\mathrm{NEt}_{4}\right] \mathrm{Cl} \cdot x \mathrm{H}_{2} \mathrm{O}$. The progress of the reaction was determined complete using infrared spectroscopy after $2 \mathrm{~h}$ of stirring. The solvent was removed in vacuo to yield a crude product. The product was recrystallized using $\mathrm{CH}_{2} \mathrm{Cl}_{2}$ and hexanes and placed in a dry ice and acetone bath to promote crystal formation. The reaction yielded $63 \mathrm{mg}$ (94\%) of powdered, white product.

\subsubsection{Synthesis of $\left[\mathrm{NEt}_{4}\right]\left[3,3,3-(\mathrm{CO})_{3}\right.$-closo- $\left.\mathrm{Re}\left(8-\mathrm{O}\left(\mathrm{CH}_{2}\right)_{2} \mathrm{O}\left(\mathrm{CH}_{2}\right)_{2} \mathrm{Br}-3,1,2-\mathrm{C}_{2} \mathrm{~B}_{9} \mathrm{H}_{10}\right)\right](5 \boldsymbol{b})$}

A solution containing $50 \mathrm{mg}(0.10 \mathrm{mmol}) \mathbf{4 b}$ in $25 \mathrm{~mL} \mathrm{CH} \mathrm{Cl}_{2}$ was treated with $22 \mathrm{mg}$ $(0.10 \mathrm{mmol})\left[\mathrm{NEt}_{4}\right] \mathrm{Br}$. The progress of the reaction was determined complete using infrared spectroscopy after $2 \mathrm{~h}$ of stirring. The solvent was removed in vacuo to yield a crude product. The product was recrystallized using $\mathrm{CH}_{2} \mathrm{Cl}_{2}$ and hexanes and placed in a dry ice and acetone bath to promote crystal formation. The reaction yielded $60 \mathrm{mg}(84 \%)$ of powdered, white product.

\subsubsection{Synthesis of $\left[\mathrm{NEt}_{4}\right]\left[3,3,3-(\mathrm{CO})_{3}-\mathrm{closo}-\mathrm{Re}\left(8-\mathrm{O}\left(\mathrm{CH}_{2}\right)_{2} \mathrm{O}\left(\mathrm{CH}_{2}\right)_{2} \mathrm{I}-3,1,2-\mathrm{C}_{2} \mathrm{~B}_{9} \mathrm{H}_{10}\right)\right](5 \mathrm{c})$}

A solution containing $50 \mathrm{mg}(0.10 \mathrm{mmol}) \mathbf{4 b}$ in $25 \mathrm{~mL}$ THF was treated with $26 \mathrm{mg}$ $(0.102 \mathrm{mmol})\left[\mathrm{NEt}_{4}\right] \mathrm{I}$. The progress of the reaction was determined complete using infrared spectroscopy after $2 \mathrm{~h}$ of stirring. The solvent was removed in vacuo to yield a crude product. The product was recrystallized using $\mathrm{CH}_{2} \mathrm{Cl}_{2}$ and hexanes and placed in a dry ice and acetone bath to promote crystal formation. The reaction yielded $68 \mathrm{mg}(90 \%)$ of powdered, white product. 
4.3.6 Synthesis of $\left[\mathrm{NEt}_{4}\right]\left[3,3,3-(\mathrm{CO})_{3}-\mathrm{closo}-\mathrm{Re}\left(8-\mathrm{O}\left(\mathrm{CH}_{2}\right)_{2} \mathrm{O}\left(\mathrm{CH}_{2}\right)_{2} \mathrm{OCH}_{2} \mathrm{Ph}-3,1,2-\mathrm{C}_{2} \mathrm{~B}_{9} \mathrm{H}_{10}\right)\right]$

(5d)

A stock solution of benzyl alcohol $(106 \mu \mathrm{L}, 1.02 \mathrm{mmol})$ and butyl lithium $(640 \mu \mathrm{L}, 1.02$ mmol) was prepared in 50mL of THF. A solution containing $50 \mathrm{mg}(0.10 \mathrm{mmol}) \mathbf{4 b}$ in $25 \mathrm{~mL}$ THF was treated with 2 equivalents of the prior prepared solution and gently refluxed. The progress of the reaction was determined complete using infrared spectroscopy after $1 \mathrm{~h}$. The solvent was removed in vacuo to yield a crude product as a lithium salt. The product was then redissolved in $25 \mathrm{~mL}$ of $\mathrm{CH}_{2} \mathrm{Cl}_{2}$ and $17 \mathrm{mg}(0.10 \mathrm{mmol})$ of $\left[\mathrm{NEt}_{4}\right] \mathrm{Cl} \cdot \mathrm{HH}_{2} \mathrm{O}$ was added. After stirring for $1 \mathrm{~h}$, the solvent was removed in vacuo and the product was columned using a 10:1 $\mathrm{CH}_{2} \mathrm{Cl}_{2}$ :MeOH ratio for the eluting solvent. The reaction yielded $56 \mathrm{mg}(75 \%)$ of an oily, pale yellow product.

\subsubsection{Synthesis of $\left[\mathrm{NBu}_{4}\right]\left[3,3,3-(\mathrm{CO})_{3}\right.$-closo-Re $\left.\left(8-\mathrm{O}\left(\mathrm{CH}_{2}\right)_{2} \mathrm{O}\left(\mathrm{CH}_{2}\right)_{2} \mathrm{~N}_{3}-3,1,2-\mathrm{C}_{2} \mathrm{~B}_{9} \mathrm{H}_{10}\right)\right](5 \boldsymbol{e})$}

A solution containing $50 \mathrm{mg}(0.10 \mathrm{mmol}) \mathbf{4 b}$ in $25 \mathrm{~mL}$ THF was treated with $29 \mathrm{mg}(0.10$ mmol) $\left[\mathrm{NBu}_{4}^{n}\right]\left[\mathrm{N}_{3}\right]$. The progress of the reaction was determined complete using infrared spectroscopy after $2 \mathrm{~h}$ of stirring. The solvent was removed in vacuo to yield a crude product. The reaction yielded $68 \mathrm{mg}(86 \%)$ of an oily, white product.

\subsubsection{Synthesis of $\left[\mathrm{NMe}_{4}\right]\left[3,3,3-(\mathrm{CO})_{3}-\mathrm{closo}-\mathrm{Re}\left(8-\mathrm{O}\left(\mathrm{CH}_{2}\right)_{2} \mathrm{O}\left(\mathrm{CH}_{2}\right)_{2} \mathrm{OH}-3,1,2-\mathrm{C}_{2} \mathrm{~B}_{9} \mathrm{H}_{10}\right)\right]$ (5f)}

A solution containing $100 \mathrm{mg}(0.20 \mathrm{mmol}) \mathbf{4 b}$ in $25 \mathrm{~mL}$ THF was treated with $36 \mathrm{mg}$ $(0.20 \mathrm{mmol})\left[\mathrm{NMe}_{4}\right][\mathrm{OH}] \cdot 5 \mathrm{H}_{2} \mathrm{O}$. The progress of the reaction was determined complete using infrared spectroscopy ca. $24 \mathrm{~h}$ of stirring. To this reaction, $\mathrm{Na}_{2} \mathrm{SO}_{4}$ was added to remove excess $\mathrm{H}_{2} \mathrm{O}$ then filtered to remove the solid. The solvent was removed in vacuo to yield a crude product. The reaction yielded $68 \mathrm{mg}(58 \%)$ of robust, brownish product. 


\subsubsection{Synthesis of $\left[3,3-(\mathrm{CO})_{2}-3-\mathrm{NO}-\right.$ closo-Re $\left.\left(8-\mathrm{O}\left(\mathrm{CH}_{2}\right)_{2} \mathrm{O}\left(\mathrm{CH}_{2}\right)_{2} \mathrm{Br}-3,1,2-\mathrm{C}_{2} \mathrm{~B}_{9} \mathrm{H}_{10}\right)\right]$ (6a)}

A solution containing $50 \mathrm{mg}(0.08 \mathrm{mmol}) \mathbf{5 a}$ in $25 \mathrm{~mL}$ THF was stirred and cooled in a acetone/dry ice bath to $-78{ }^{\circ} \mathrm{C}$. Upon chilling, ca. $9 \mathrm{mg}(0.08 \mathrm{mmol})[\mathrm{NO}]\left[\mathrm{BF}_{4}\right]$ was added to the solution. The reaction was allowed to return to room temperature while stirring ca. $2-3 \mathrm{~h}$. The progress of the reaction was determined complete using infrared spectroscopy. The solvent was removed in vacuo to yield a crude product. The product was then columned in neat $\mathrm{CH}_{2} \mathrm{Cl}_{2}$ and recrystallized using $\mathrm{CH}_{2} \mathrm{Cl}_{2}$ and hexanes and placed in a dry ice and acetone bath to promote crystal formation. The reaction yielded $36 \mathrm{mg}(91 \%)$ of powdered, bright yellow product.

\subsubsection{Synthesis of [3,3-(CO) $\left.{ }_{2}-3-\mathrm{NO}-\mathrm{closo}-\mathrm{Re}\left(8-\mathrm{O}\left(\mathrm{CH}_{2}\right)_{2} \mathrm{O}\left(\mathrm{CH}_{2}\right)_{2} \mathrm{Br}-3,1,2-\mathrm{C}_{2} \mathrm{~B}_{9} \mathrm{H}_{10}\right)\right](\mathbf{6 b})$}

A solution containing $50 \mathrm{mg}(0.07 \mathrm{mmol}) \mathbf{5 b}$ in $25 \mathrm{~mL}$ THF was stirred and cooled in a acetone/dry ice bath to $-78{ }^{\circ} \mathrm{C}$. Upon chilling, ca. $8 \mathrm{mg}(0.07 \mathrm{mmol})[\mathrm{NO}]\left[\mathrm{BF}_{4}\right]$ was added to the solution. The reaction was allowed to return to room temperature while stirring ca. $2-3 \mathrm{~h}$. The progress of the reaction was determined complete using infrared spectroscopy. The solvent was removed in vacuo to yield a crude product. The product was then columned in neat $\mathrm{CH}_{2} \mathrm{Cl}_{2}$ and recrystallized using $\mathrm{CH}_{2} \mathrm{Cl}_{2}$ and hexanes and placed in a dry ice and acetone bath to promote crystal formation. The reaction yielded $27 \mathrm{mg}(65 \%)$ of powdered, bright yellow product.

\subsubsection{Synthesis of $\left[3,3-(\mathrm{CO})_{2}-3-\mathrm{NO}-\right.$ closo- $\left.\mathrm{Re}\left(8-\mathrm{O}\left(\mathrm{CH}_{2}\right)_{2} \mathrm{O}\left(\mathrm{CH}_{2}\right)_{2} \mathrm{I}-3,1,2-\mathrm{C}_{2} \mathrm{~B}_{9} \mathrm{H}_{10}\right)\right]$ (6c)}

A solution containing $50 \mathrm{mg}(0.07 \mathrm{mmol}) \mathbf{5} \mathbf{c}$ in $25 \mathrm{~mL}$ THF was stirred and cooled in a acetone/dry ice bath to $-78^{\circ} \mathrm{C}$. Upon chilling, ca. $8 \mathrm{mg}(0.07 \mathrm{mmol})[\mathrm{NO}]\left[\mathrm{BF}_{4}\right]$ was added to the solution. The reaction was allowed to return to room temperature while stirring ca. 2-3 h. The progress of the reaction was determined complete using infrared spectroscopy. The solvent was removed in vacuo to yield a crude product. The product was then columned in neat $\mathrm{CH}_{2} \mathrm{Cl}_{2}$ and 
recrystallized using $\mathrm{CH}_{2} \mathrm{Cl}_{2}$ and hexanes and placed in a dry ice and acetone bath to promote crystal formation. The reaction yielded $37 \mathrm{mg}$ (90\%) of powdered, bright yellow product.

\subsubsection{Synthesis of [3,3-(CO) ${ }_{2}-3-\mathrm{NO}-$ closo- $\left.\mathrm{Re}\left(8-\mathrm{O}\left(\mathrm{CH}_{2}\right)_{2} \mathrm{O}\left(\mathrm{CH}_{2}\right)_{2} \mathrm{OCH}_{2} \mathrm{Ph}-3,1,2-\mathrm{C}_{2} \mathrm{~B}_{9} \mathrm{H}_{10}\right)\right]$ (6d)}

A solution containing $50 \mathrm{mg}(0.07 \mathrm{mmol}) \mathbf{5 d}$ in $25 \mathrm{~mL}$ THF was stirred and cooled in a acetone/dry ice bath to $-78{ }^{\circ} \mathrm{C}$. Upon chilling, ca. $8.06 \mathrm{mg}(0.07 \mathrm{mmol})[\mathrm{NO}]\left[\mathrm{BF}_{4}\right]$ was added to the solution. The reaction was allowed to return to room temperature while stirring ca. $2-3 \mathrm{~h}$. The progress of the reaction was determined complete using infrared spectroscopy. The solvent was removed in vacuo to yield a crude product. The reaction yielded $29 \mathrm{mg}(71 \%)$ of oily, yellowbrown product.

\subsubsection{Synthesis of [3,3-(CO) ${ }_{2}-3-\mathrm{NO}-$ closo-Re $\left.\left(8-\mathrm{O}\left(\mathrm{CH}_{2}\right)_{2} \mathrm{O}\left(\mathrm{CH}_{2}\right)_{2} \mathrm{OTf}-3,1,2-\mathrm{C}_{2} \mathrm{~B}_{9} \mathrm{H}_{10}\right)\right](6 \boldsymbol{e})$}

An NMR tube containing $5 \mathrm{mg}(0.01 \mathrm{mmol}) \mathbf{6 c}$ and $10 \mathrm{mg}(0.04 \mathrm{mmol}) \mathrm{Ag}\left[\mathrm{CF}_{3} \mathrm{SO}_{3}\right]$ was dissolved in $0.7 \mathrm{~mL}$ toluene- $\mathrm{d}_{8}$ and placed into an NMR spectrometer. The probe of the NMR heated the reaction vessel to $50{ }^{\circ} \mathrm{C}$ where reaction progress was monitored through subsequent ${ }^{1} \mathrm{H}$ NMR scans for $2 \mathrm{~h}$. No product isolation has proved successful to this point, product may be very sensitive or possess a very short lifespan.

\subsubsection{Synthesis of [3,3-(CO) ${ }_{2}-3-\mathrm{NO}-$ closo- $\left.\mathrm{Re}\left(8-\mathrm{O}\left(\mathrm{CH}_{2}\right)_{2} \mathrm{O}\left(\mathrm{CH}_{2}\right)_{2} \mathrm{OH}-3,1,2-\mathrm{C}_{2} \mathrm{~B}_{9} \mathrm{H}_{10}\right)\right]$ (6f)}

A solution containing $50 \mathrm{mg}(0.09 \mathrm{mmol}) \mathbf{5 f}$ in $25 \mathrm{~mL}$ THF was stirred and cooled in a acetone/dry ice bath to $-78{ }^{\circ} \mathrm{C}$. Upon chilling, ca. $10 \mathrm{mg}(0.09 \mathrm{mmol})[\mathrm{NO}]\left[\mathrm{BF}_{4}\right]$ was added to the solution. The reaction was allowed to return to room temperature while stirring ca. $2-3 \mathrm{~h}$. The progress of the reaction was determined complete using infrared spectroscopy. The solvent was 
removed in vacuo to yield a crude product. The reaction yielded $23 \mathrm{mg}(52 \%)$ of an oily, bright yellow product.

\subsubsection{Synthesis of [3,3-(CO) ${ }_{2}-3-\mathrm{NO}-$ closo- $\left.\mathrm{Re}\left(8-\mathrm{O}\left(\mathrm{CH}_{2}\right)_{2} \mathrm{O}\left(\mathrm{CH}_{2}\right)_{2} \mathrm{NH}_{3}-3,1,2-\mathrm{C}_{2} \mathrm{~B}_{9} \mathrm{H}_{10}\right)\right]$ (7)}

A solution containing $75 \mathrm{mg}(0.15 \mathrm{mmol}) \mathbf{4 b}$ in $20 \mathrm{~mL}$ THF was treated with excess $\left[\mathrm{NH}_{4}\right][\mathrm{OH}](50 \mu \mathrm{L}, 1.25 \mathrm{mmol})$. The progress of the reaction was determined complete using infrared spectroscopy after $1 \mathrm{~h}$ of stirring. To this reaction, $\mathrm{Na}_{2} \mathrm{SO}_{4}$ was added to remove excess $\mathrm{H}_{2} \mathrm{O}$ then filtered to remove the solid. The solvent was removed in vacuo to yield a crude product. The product was further dried in vacuo by placing the flask in a $60{ }^{\circ} \mathrm{C}$ water bath for 4 h. The reaction yielded $72 \mathrm{mg}$ (93\%) of powdered, pale tan product.

\subsubsection{Synthesis of [3,3-(CO) ${ }_{2}-3-\mathrm{NO}-$ closo- $\left.\mathrm{Re}\left(8-\mathrm{O}\left(\mathrm{CH}_{2}\right)_{2} \mathrm{O}\left(\mathrm{CH}_{2}\right)_{2} \mathrm{NH}_{3}-3,1,2-\mathrm{C}_{2} \mathrm{~B}_{9} \mathrm{H}_{10}\right)\right]\left[\mathrm{BF}_{4}\right](\mathbf{8})$}

A solution containing $100 \mathrm{mg}(0.20 \mathrm{mmol}) 7 \mathrm{in} 20 \mathrm{~mL}$ THF was stirred and cooled in a acetone/dry ice bath to $-78^{\circ} \mathrm{C}$. Upon chilling, ca. $23 \mathrm{mg}(0.20 \mathrm{mmol})[\mathrm{NO}]\left[\mathrm{BF}_{4}\right]$ was added to the solution. The reaction was allowed to return to room temperature while stirring ca. $2-3 \mathrm{~h}$. The progress of the reaction was determined complete using infrared spectroscopy. The solvent was removed in vacuo to yield $102 \mathrm{mg}(87 \%)$ of an oily, bright yellow product.

\subsection{Crystal structure analysis of complex $6 \mathrm{c}$}

A translucent light yellow-red leaf-like specimen of $\mathrm{C}_{6} \mathrm{H}_{18} \mathrm{~B}_{9} \mathrm{IN}_{2} \mathrm{O}_{5} \mathrm{Re}$, approximate dimensions $0.040 \mathrm{~mm} \times 0.180 \mathrm{~mm} \times 0.190 \mathrm{~mm}$, was used for the X-ray crystallographic analysis. The X-ray intensity data were measured on a Bruker Smart Apex II-D8 diffractometer using Mo-K $\mathrm{K}_{\alpha}$ radiation $(\lambda=0.71073 \AA)$ at $1446(2) \mathrm{K}$. A total of 6243 frames were collected. The total exposure time was 17.34 hours. The frames were integrated with the Bruker SAINT 
software package using a narrow-frame algorithm. The integration of the data using a triclinic unit cell yielded a total of 94263 reflections to a maximum $\theta$ angle of $29.93^{\circ}(0.71 \AA$ resolution $)$, of which 10297 were independent (average redundancy 9.154, completeness $=97.3 \%, R_{\text {int }}=$ $\left.4.03 \%, R_{\text {sig }}=2.18 \%\right)$ and $9596(93.19 \%)$ were greater than $2 \sigma\left(F^{2}\right)$. The final cell constants of $a=$ 12.2638(4) $\AA, b=12.8143(4) \AA, c=13.5752(5) \AA, \alpha=107.089(2)^{\circ}, \beta=114.700(2)^{\circ}, \gamma=$ $91.129(2)^{\circ}$, volume $=1827.50(11) \AA^{3}$, are based upon the refinement of the XYZ-centroids of 9672 reflections above $20 \sigma(\mathrm{I})$ with $4.701^{\circ}<2 \theta<59.80^{\circ}$. Data were corrected for absorption effects using the multi-scan method (SADABS). The ratio of minimum to maximum apparent transmission was 0.585 . The calculated minimum and maximum transmission coefficients (based on crystal size) are 0.3000 and 0.7310 . The structure was solved and refined using the Bruker SHELXTL Software Package, using the space group P $\overline{1}$, with $Z=4$ for the formula unit, $\mathrm{C}_{6} \mathrm{H}_{18} \mathrm{~B}_{9} \mathrm{IN}_{2} \mathrm{O}_{5} \mathrm{Re}$. The final anisotropic full-matrix least squares refinement on $F^{2}$ with 596 variables converged at $R 1=2.93 \%$, for the observed data and $w R 2=7.99 \%$ for all data. The goodness-of-fit was 1.061. The largest peak in the final difference electron density synthesis was $6.286 \mathrm{e} / \AA^{3}$ and the largest hole was $-1.659 \mathrm{e} / \AA^{3}$ with an RMS deviation of $0.228 \mathrm{e} / \AA^{3}$. On the basis of the final model, the calculated density was $2.248 \mathrm{~g} / \mathrm{cm}^{3}$ and $F(000), 1144 \mathrm{e}$.

\section{Acknowledgement}

Acknowledgement is made to the National Science Foundation for support under grant CHE0963363 for renovations to the research laboratories in Monsanto Hall at Saint Louis University. 


\section{References}

[1] W.A. Banks, M.B. Fasold, A.J. Kastin, in:, G.B. Irvine, C.H. Williams (Eds.), Neuropept. Protoc., Humana Press, 1997, pp. 353-360.

[2] E. Neuwelt, N.J. Abbott, L. Abrey, W.A. Banks, B. Blakley, T. Davis, B. Engelhardt, P. Grammas, M. Nedergaard, J. Nutt, W. Pardridge, G.A. Rosenberg, Q. Smith, L.R. Drewes, Lancet Neurol. 7 (2008) 84.

[3] W.A. Banks, BMC Neurol. 9 (2009) S3.

[4] W.H. Oldendorf, Proc. Soc. Exp. Biol. Med. Soc. Exp. Biol. Med. N. Y. N 147 (1974) 813.

[5] D.J. Begley, Curr. Pharm. Des. 10 (2004) 1295.

[6] J.F. Valliant, P. Morel, P. Schaffer, J.H. Kaldis, Inorg. Chem. 41 (2002) 628.

[7] J.F. Valliant, O.O. Sogbein, P. Morel, P. Schaffer, K.J. Guenther, A.D. Bain, Inorg. Chem. $41(2002) 2731$.

[8] O.O. Sogbein, P. Merdy, P. Morel, J.F. Valliant, Inorg. Chem. 43 (2004) 3032.

[9] P.M. Hawkins, P.A. Jelliss, N. Nonaka, X. Shi, W.A. Banks, J. Pharmacol. Exp. Ther. 329 (2009) 608.

[10] D.D. Ellis, P.A. Jelliss, F.G.A. Stone, Chem. Commun. (1999) 2385.

[11] D.F. Mullica, E.L. Sappenfield, F.G.A. Stone, S.F. Woollam, Organometallics 13 (1994) 157.

[12] M. Hata, J.A. Kautz, X.L. Lu, T.D. McGrath, F.G.A. Stone, Organometallics 23 (2004) 3590.

[13] P. Farràs, F. Teixidor, R. Kivekäs, R. Sillanpää, C. Viñas, B. Grüner, I. Cisarova, Inorg. Chem. 47 (2008) 9497.

[14] M. Otsuru, K. Tori, J.M. Lehn, R. Seher, J. Am. Chem. Soc. 91 (1969) 1187.

[15] C.D. Beard, K. Baum, J. Org. Chem. 39 (1974) 3875. 


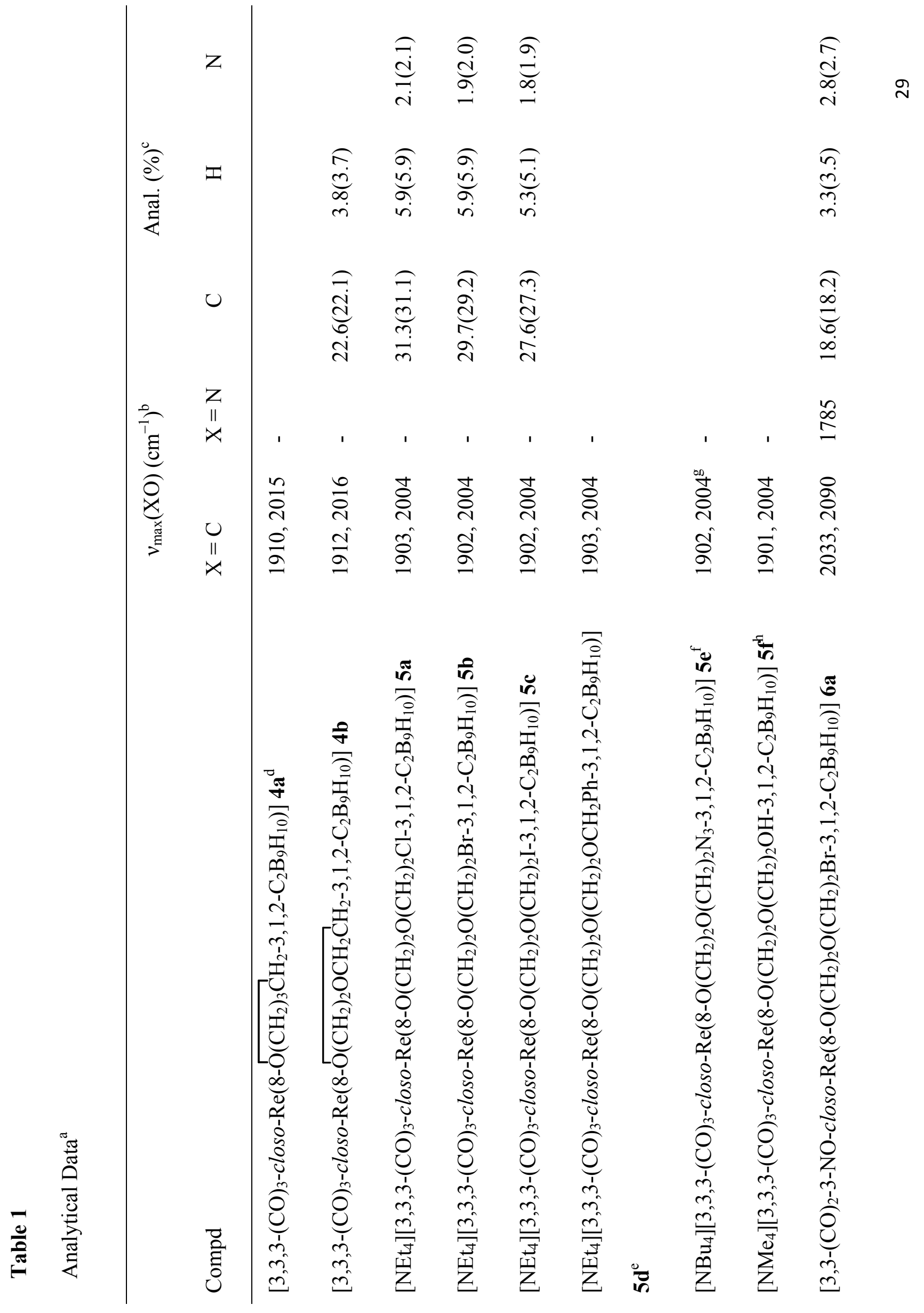




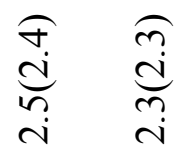

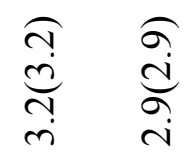

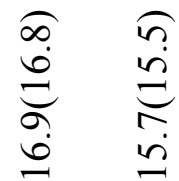

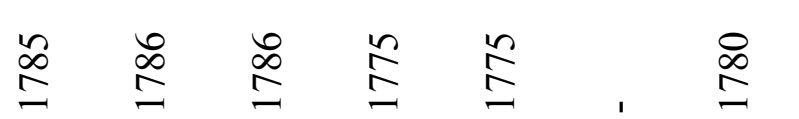

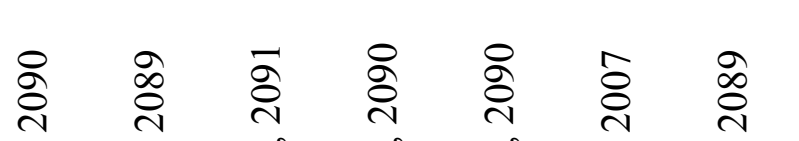

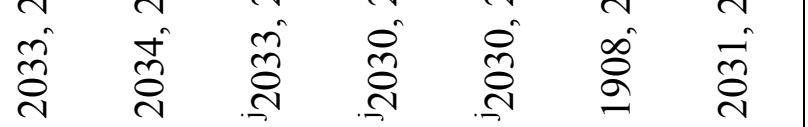

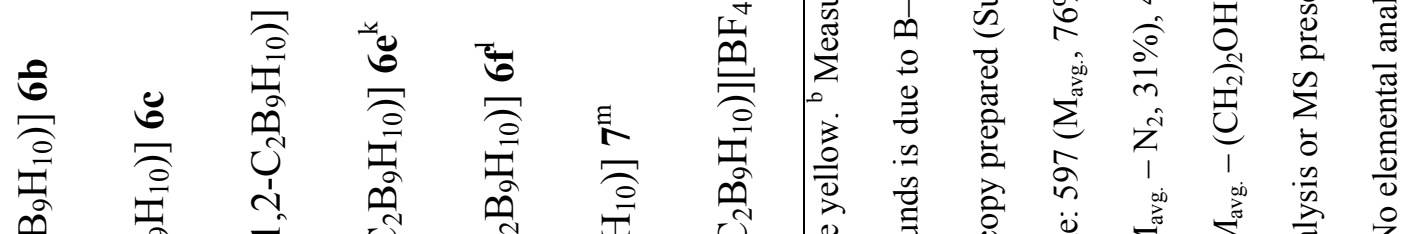

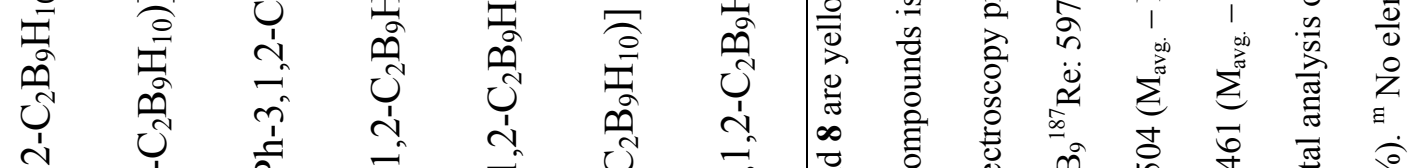

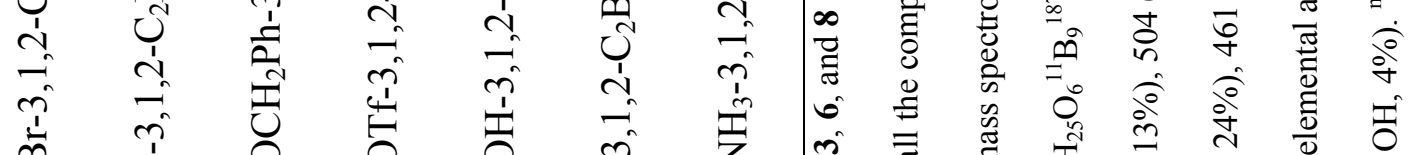

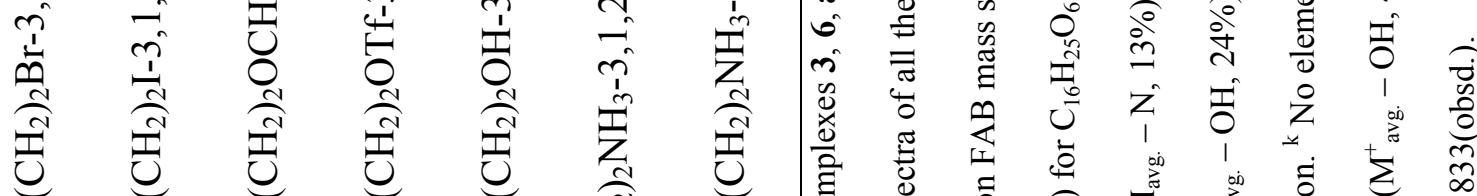

당

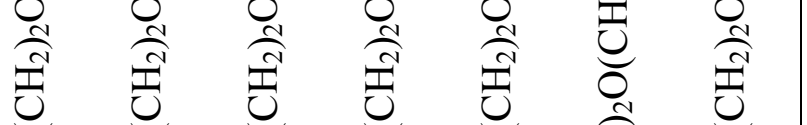

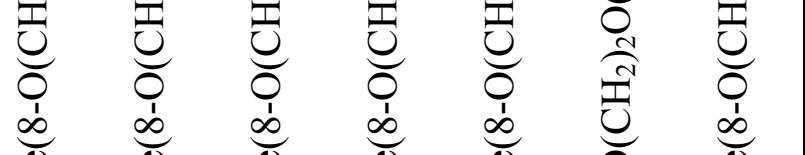

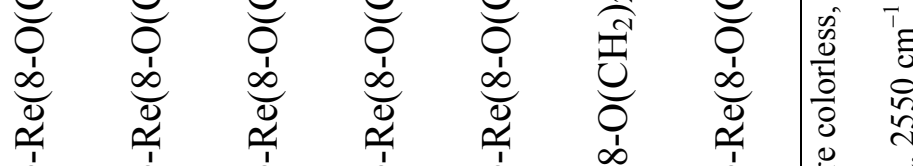

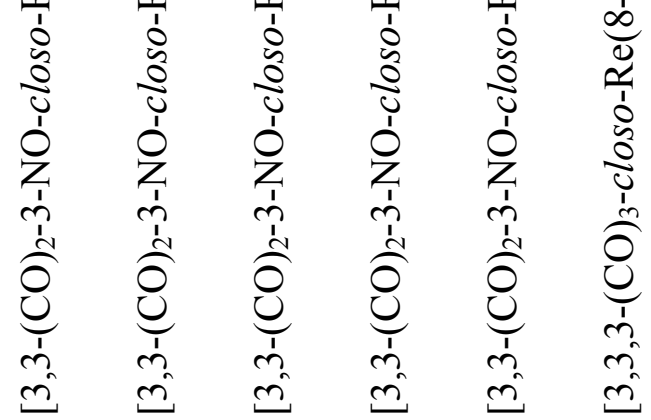

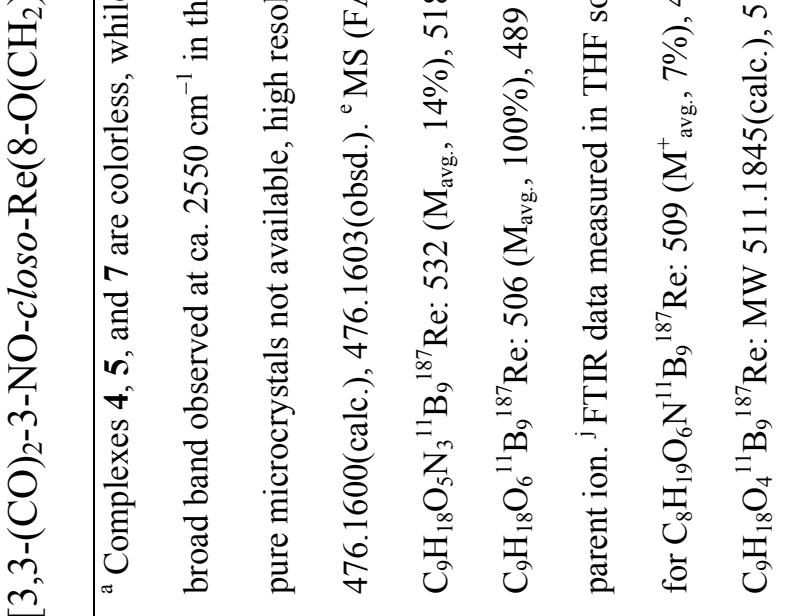




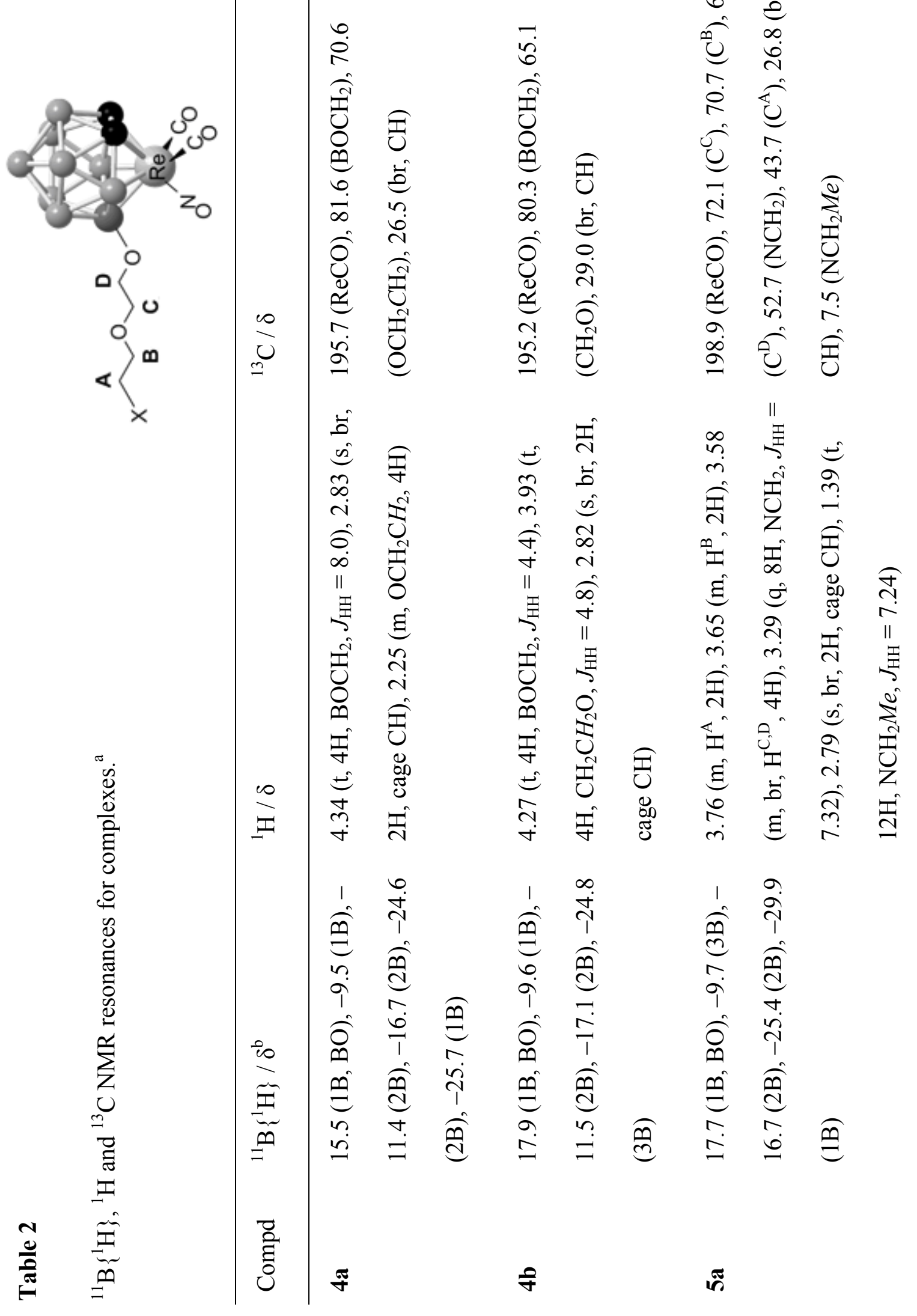

จิ

()

N

U

$\underset{7}{\pi}$

I

¿ Z Z

in $N$

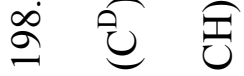




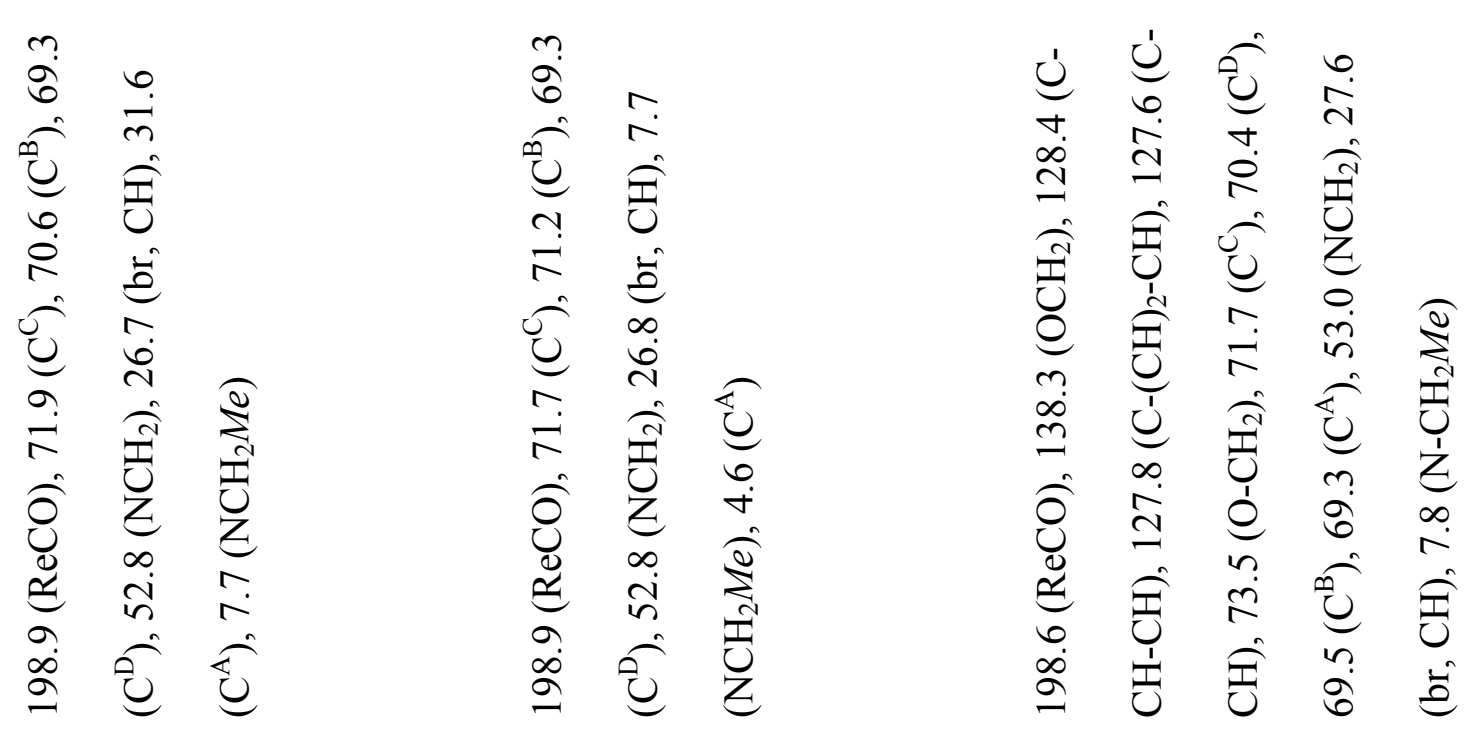

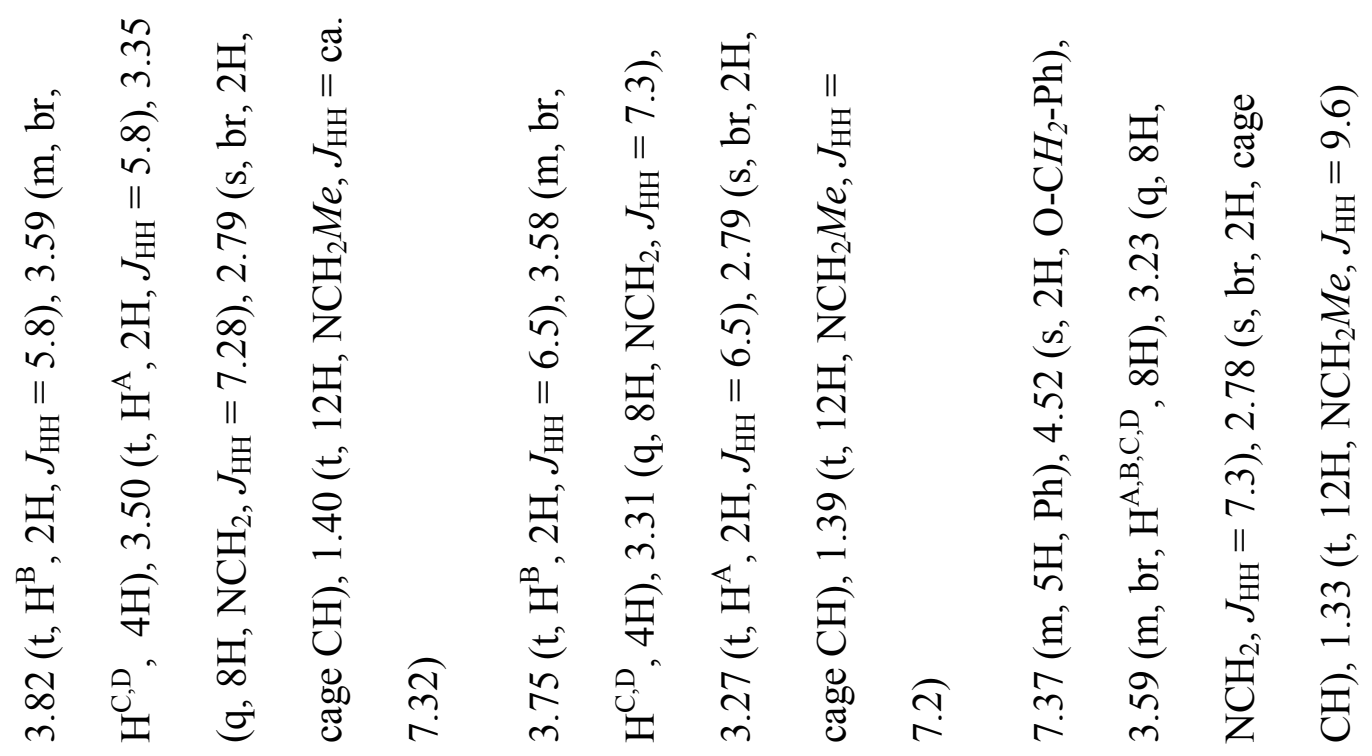

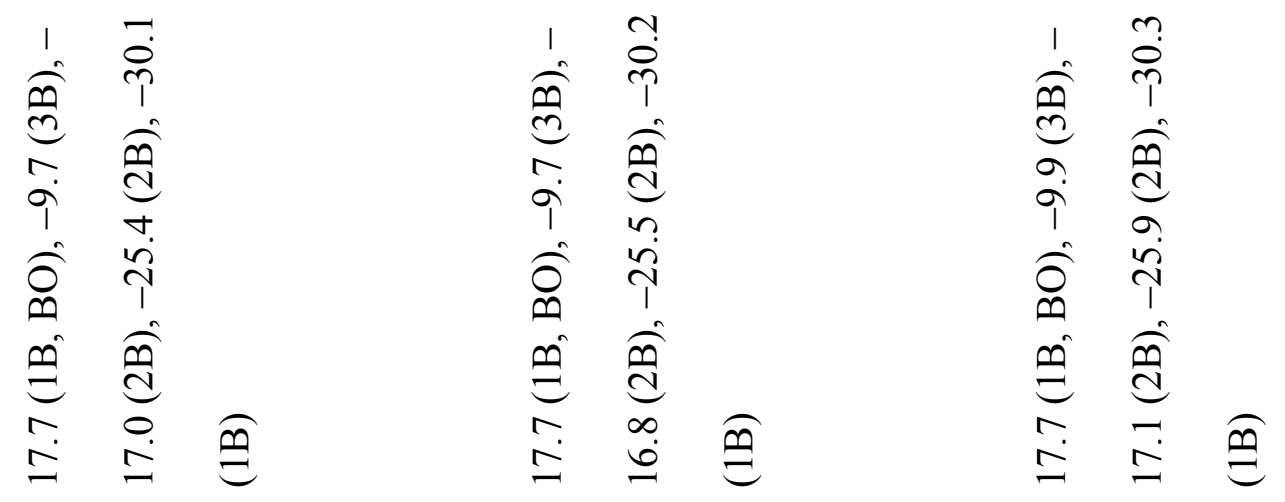



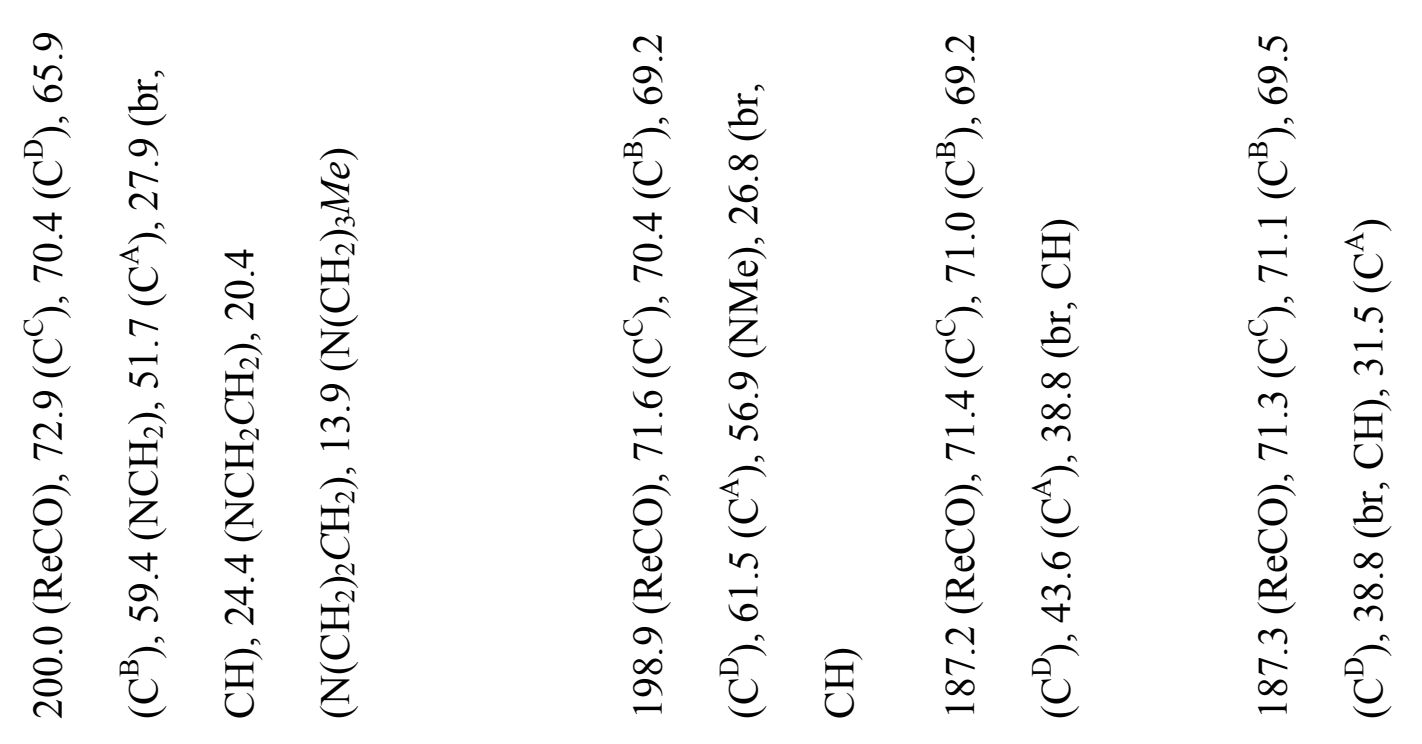

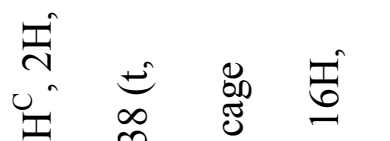

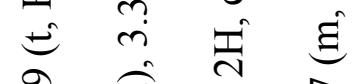

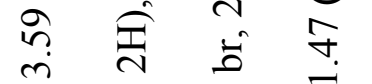

के

$\because$ 苛

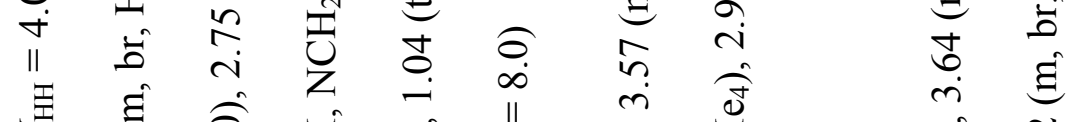

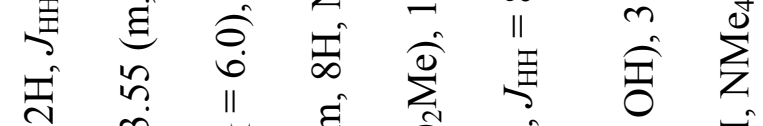

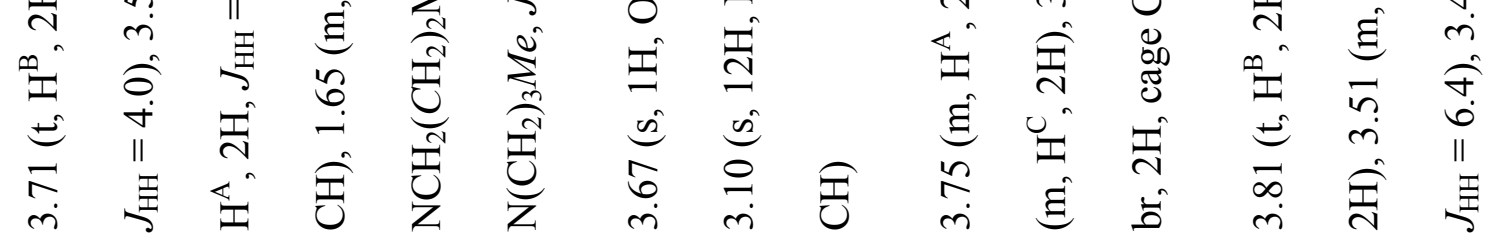

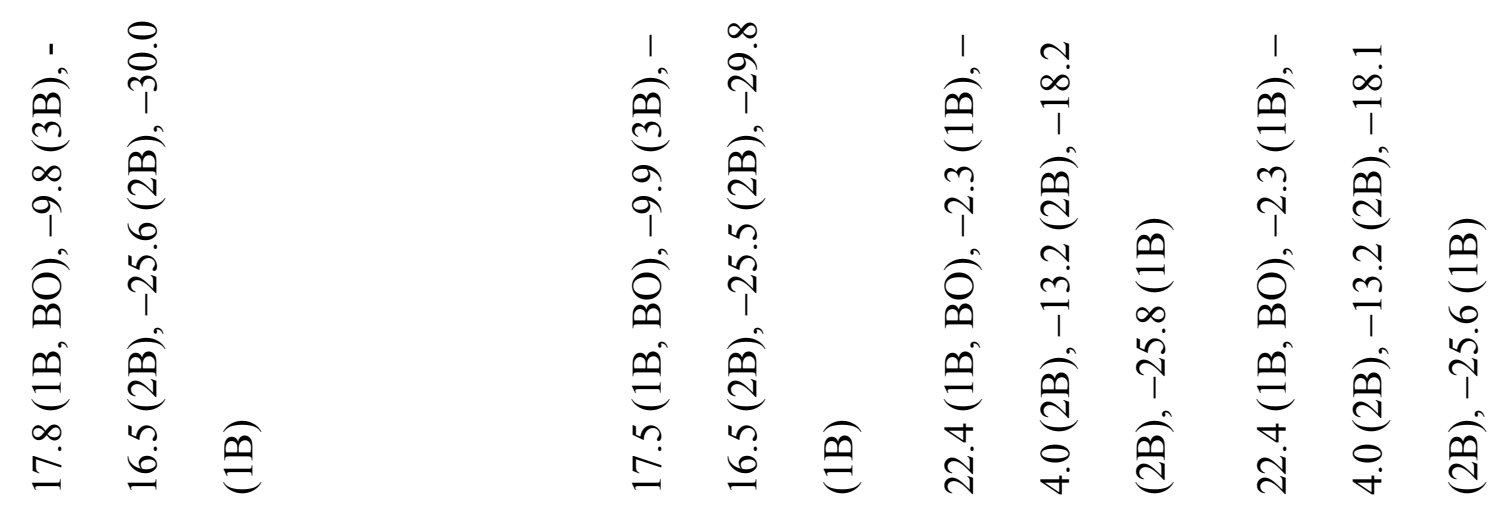




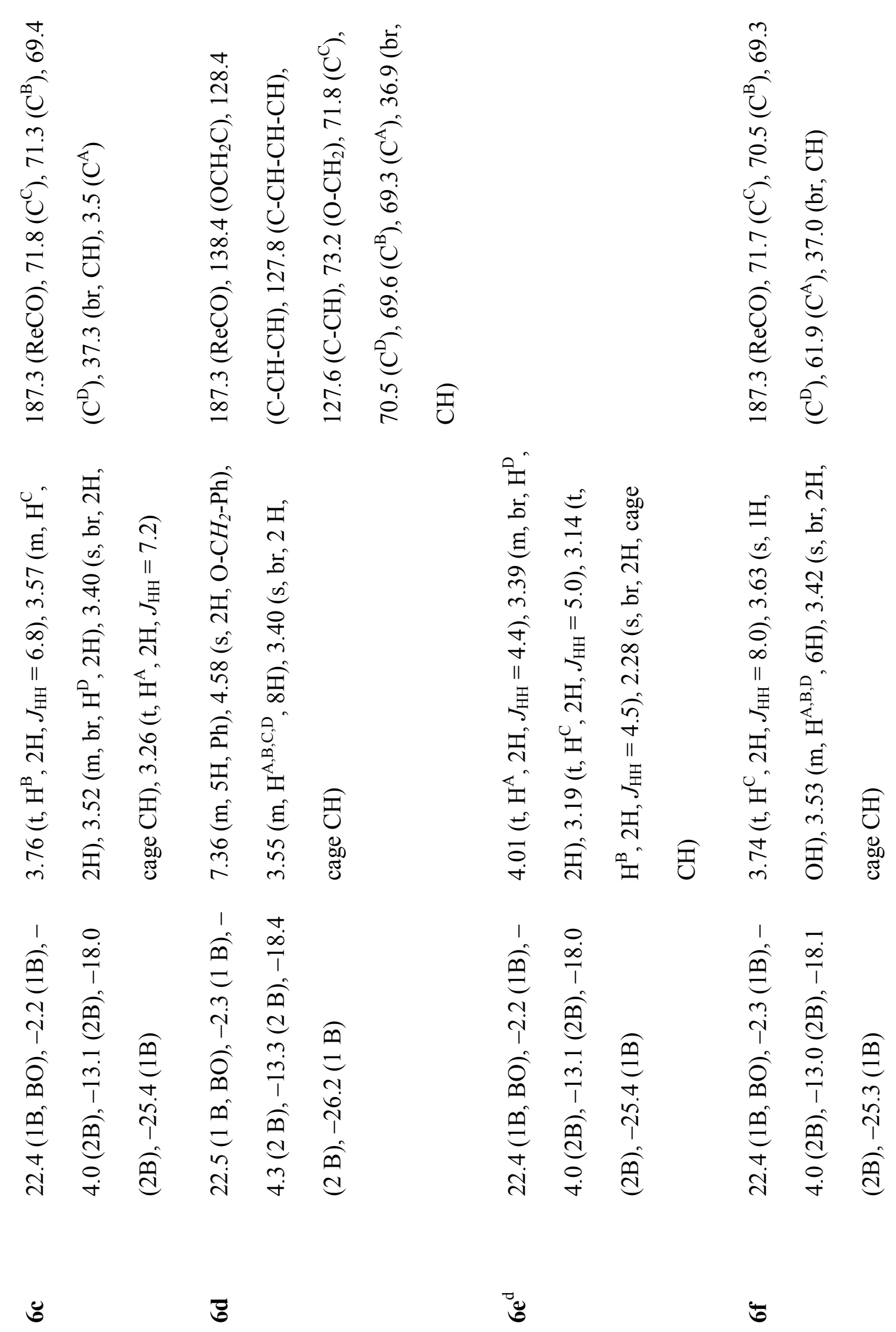




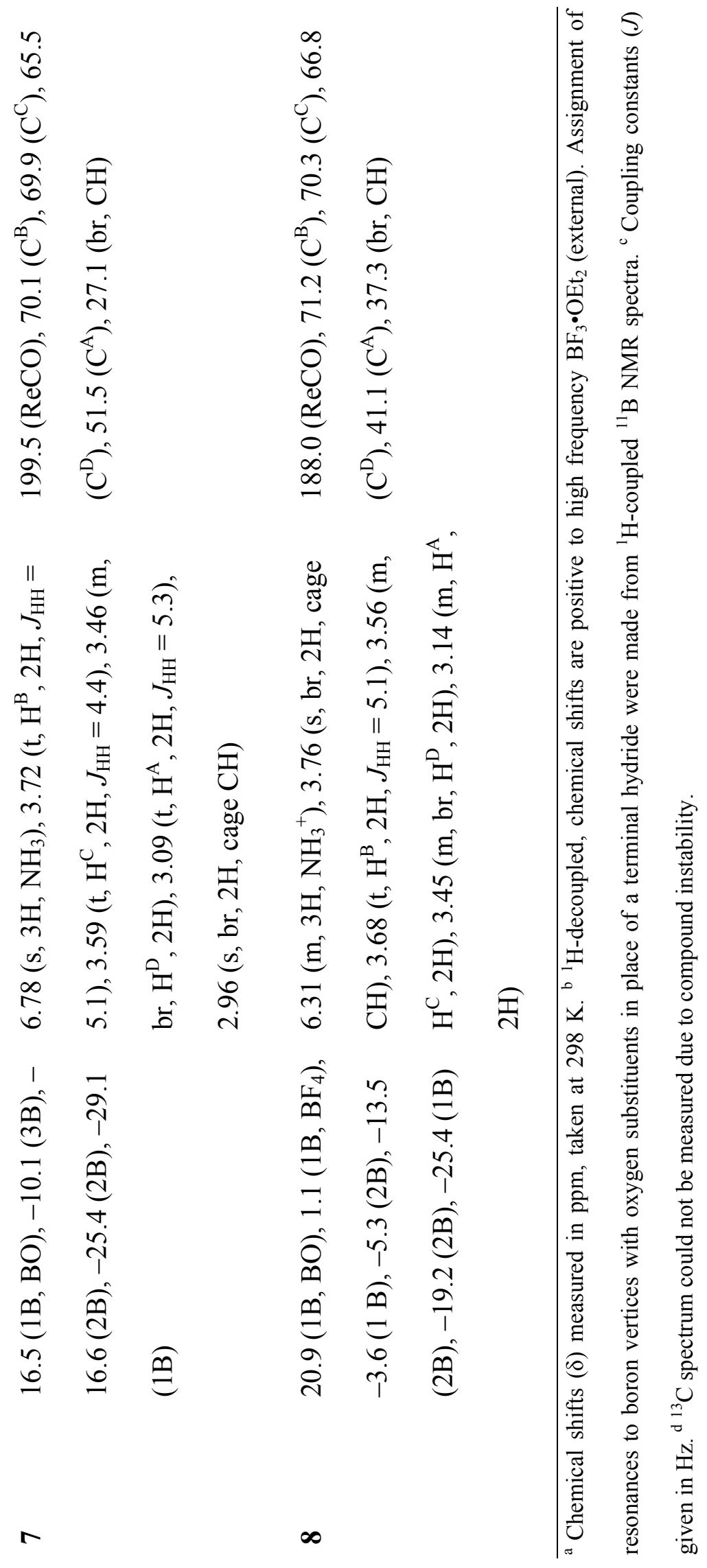


Graphical abstract
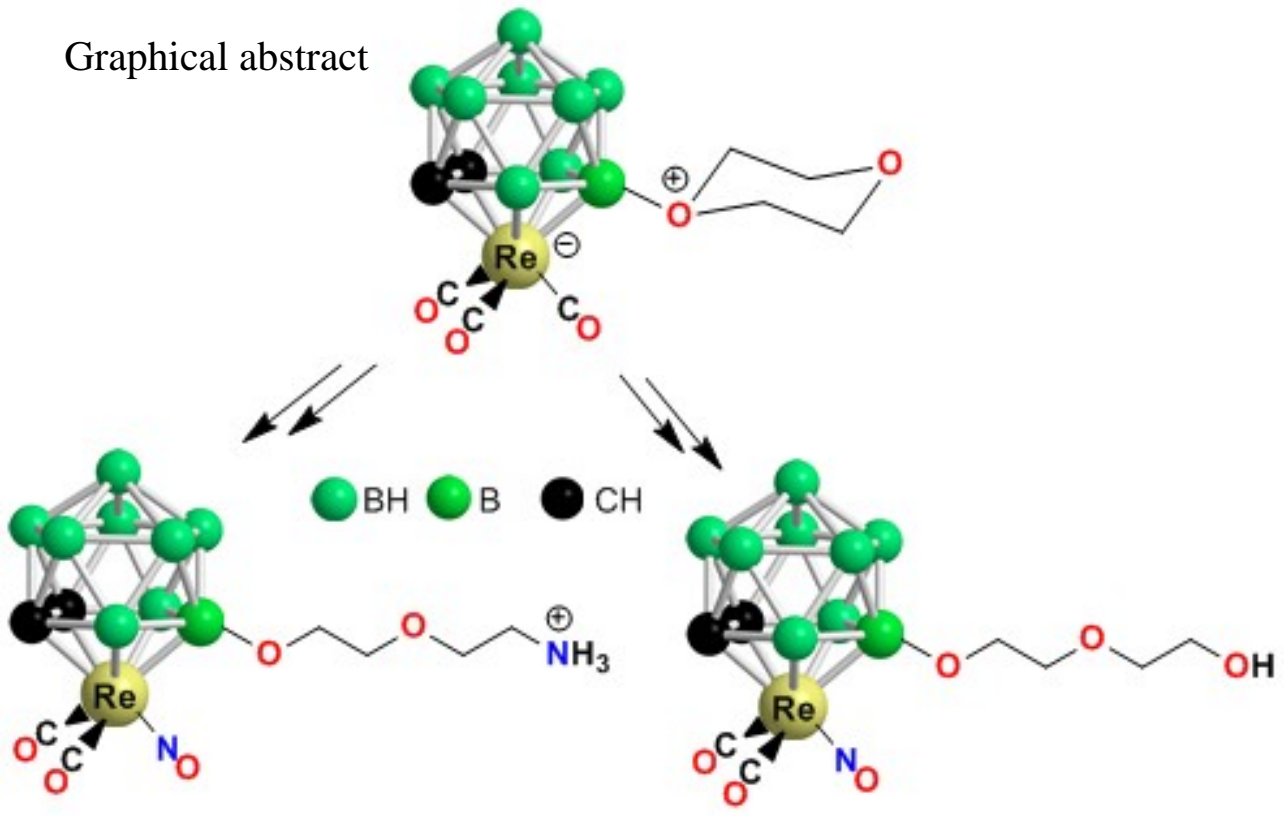